\title{
Multidimensional examination of the performances of a liner shipping network: trunk line/route operated by conventional (Panamax Max) and mega (ULC - ultra large container) ships
}

Milan Janić

\author{
Correspondence: M.Janic@tudelft.nl \\ Faculty of Civil Engineering and \\ Geosciences, Department of \\ Transport \& Planning, Delft \\ University of Technology, Stevinweg \\ 1, 2628, BX, Delft, The Netherlands
}

\begin{abstract}
This paper deals multidimensional examination of performances of a trunk line/route of liner container-shipping network serving an intercontinental supply chain by the conventional (Panamax Max) and mega (ULC - Ultra Large Container) ships. The trunk line/route of the network includes the supplier and the customer seaport of freight shipments consolidated into containers (TEU (Twenty Foot Equivalent Unit)), and the container ships operated by liner shipping carriers and/or their alliances providing transport services between them. The supplier and the customer seaport can be either the main seaports of the line or the hubs of the H\&S (Hub-and-Spoke) network of particular liner container-shipping carriers.

The multidimensional examination implies defining and developing the analytical models of indicators of the trunk line's infrastructural, technical/technological, operational, economic, environmental, and social performances and their application to the selected real-life case. The infrastructural performances relate to the characteristics of infrastructure (berths) and container terminals in the seaports at both ends of the line. The technical/technological performances reflect the characteristics of facilities and equipment for loading/unloading and storing TEU shipments in these terminals, and that of the container ships transporting them. The operational performances include the transport service frequency, size, transport work and technical productivity of the deployed container ship fleet while serving a given volume of TEU flows during the specified time. The economic performances contain the inventory, handling, transport, and external costs of handling the TEU flows. The environmental performances relate to the fuel consumption and consequent emissions of GHG (Green House Gases). Finally, the social performances in terms of impacts generally refer to noise, congestion, and safety.

The models of indicators of performances have been applied to the liner containershipping trunk line/route connecting the East Asia and North Europe operated exclusively by two above-mentioned categories of ships according to the "what-if" scenario approach. The results have indicated the very high sensitivity of all considered indicators of performances to the category of deployed ships under given conditions. As well, they have shown to be dependent on each other - the operational on the (Continued on next page)
\end{abstract}


(Continued from previous page)

technical/technological, and the economic, environmental, and social on the technical/ technological and operational.

Keywords: Liner container-shipping networks, Trunk line/route, Performances, Indicators, Analytical models, Conventional and mega container ships

\section{Introduction}

With globalization of the world's economy, many supply chains have become increasingly global spreading between particular continents. On the one hand, the growing container shipping industry has supported and further stimulated their development. On the other, such newly developed supply chains have put increasing requirements on the industry in terms of providing high quality and reasonable price of services. Under such circumstances, the container shipping industry has been developing relatively fast during the past decades. This particularly relates to the size and payload capacity of deployed container ships operating in the liner shipping networks which have increased over time while serving increasingly global supply chains. The main driving forces of such development have generally been: i) Growing volumes and spatial diversity of the freight transport demand combined with its increased internalization, globalization, and consequently consolidation, i.e., containerization; ii) Strengthening competition in the maritime freight transport markets forcing the liner container-shipping carriers to permanently improve effectiveness (i.e., reliability, punctuality, safety) and efficiency (by deploying larger container ships and taking advantages of their economies of scale) of their services; iii) Raising concerns on the impacts of freight transport sector and its maritime transport mode including the container-shipping segment on the environment and society; and iv) Innovative design, materials, and the manufacturing processes of container ships, the container handling supportive facilities and equipment, and the seaport infrastructure (Christa et al. 2008; Cullinane and Khanna 2000; ITF 2015; Kapoor 2016; UNCTAD 2017; Vad Karsten 2015; Van Marle 2013). Figure 1 shows an example of the relationships between the demand and capacity in the global maritime container transport market.

As can be seen, during the observed period (1980-2016), the payload capacity of the global maritime container ship fleet has increased more than proportionally, driven by

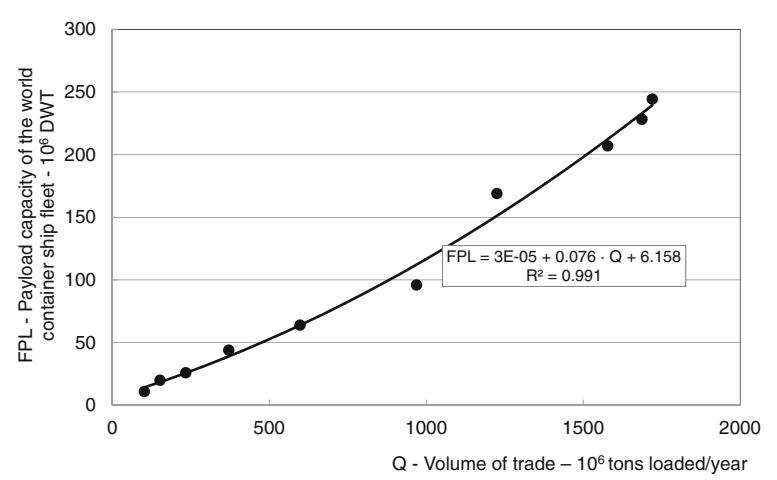

Fig. 1 The containerized freight seaborne trade vs the capacity of container ship fleet (DWT - Dead Weight Tonnage) (Period: 1980-2016) (UNCTAD 2017) 
the need for satisfying growing increasingly globalized and containerized freight transport demand (TEU (Twenty Foot Equivalent Unit) flows. In addition, the average payload capacity of the maritime container ships has also been increasing over time as shown in Fig. 2.

On the one hand, the larger container ships with a greater payload capacity usually run fewer transport services and the corresponding total ship-miles while transporting the given volumes of TEU flows along the same routes than those of their smaller counterparts. On the other, these ships have greater empty weight, higher energy (fuel) consumption, the total cost per service in addition to the constraints in calling the particular seaports, and more effort in providing the sufficient quantity of demand, i.e., load factor, for carrying out the profitable services (Ducruet and Notteboom 2011; Van Marle 2013). The latest particularly applies to the specific category of these ships referred as the mega or ULC ships considered as the largest in terms of their size, i.e., external dimensions - length, beam (width), draft, and the payload capacity (DWT (Dead Weight Tonnage), TEU), all compared to their closest (smaller) counterparts.

This paper deals with the multidimensional examination of performances of a trunk line/route of a liner container-shipping network operated by either conventional (Panamax Max) or mega or ULC (Ultra Large Container) ships. This implies handling and direct transportation (without the intermediate port calls) of TEU flows between their origin seaport as the line's supplier and the destination seaport as the line's customer. The collection and distribution of these flows to/from these origin/destination seaports, respectively, are not taken into account.

In addition to this introductory, the paper consists of four other sections. Section 2 describes the characteristic configurations of the liner container-shipping networks and the concept of their performances. Section 3 updates the existing and develops the novel analytical models of indicators of the particular performances of the above-mentioned trunk line/route of the liner shipping network serving a given supply chain according to the specified "what-if" scenario under given conditions. Section 4 presents an application of the proposed models of indicators of performances to the trunk line/ route exclusively operated by the conventional (Panamax Max) and the mega or ULC ships. The last section contains some conclusions and discussion about some advantages

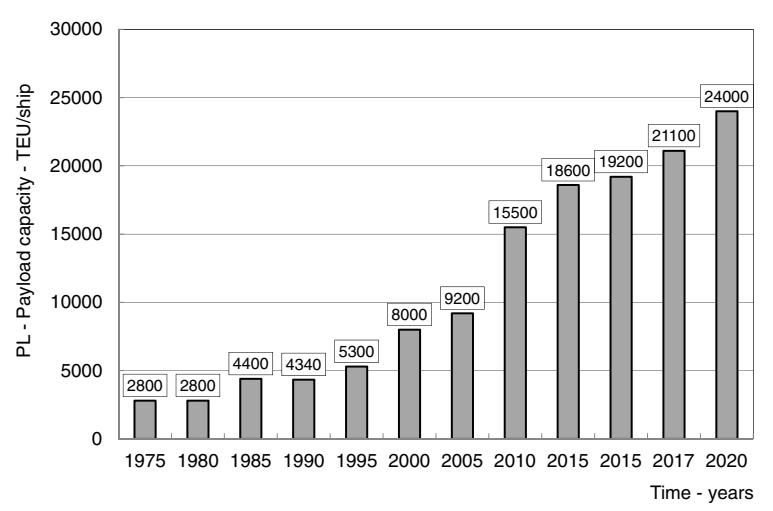

Fig. 2 Development of the payload capacity of the maritime container ships over time (Period: 1975-2016) (Rodrigue et al. 2017; ITF 2015; UNCTAD 2017) 
and disadvantages for the main actors/stakeholders from deploying mega (ULC) ships for serving the intercontinental supply chains under given conditions.

\section{Configurations of the liner shipping networks and concept of their performances \\ Configurations of the networks}

The existing liner container-shipping networks worldwide serving the intercontinental supply chains have shown to be very diverse regarding the types of offered transport services, the network spatial/operational complexity in terms of the strength of presence on the global and secondary lines/routes, and the types of bundling of TEU flows. Regarding the strength of presence on the global and secondary lines/routes, they have been roughly categorized into H\&S (Hub-and-Spoke), ETE (End-To-End), RTW (Round-The-World), pendulum, and triangle (Tran and Haasis 2015). Regarding the type of bundling of TEU flows, they have been categorized as: i) Bundling with and individual liner service; and ii) Bundling by combining/linking two or more liner services (Ducruet and Notteboom 2012). In the former case, the network carriers collect the TEU flows by calling different ports along the given trunk line/route constrained by the origin and destination seaports, i.e., they operate the MPC (Multi-Port-Call) network configurations. In the latter case, the TEU flows are collected at the seaports usually located at the intersections of the main maritime trade routes and additionally consolidated by the feeder short-sea and inland transport services. The same or different carriers and/or their alliances as that operating the trunk line/main route between the hubs can carry out the short-sea shipping feeder services. The road and rail transport mode and their systems usually provide the inland transport services. Consequently, these seaports operate as hubs of the H\&S networks of the liner container-shipping carriers and/or their alliances (Panayides and Wiedmer 2011). In these networks, the trunk lines/routes usually connect a pair of hubs by the shipping services carried out with much less or no intermediate port calls compared to the MPC counterparts. Due to concentration of the TEU flows at hubs the ships are sufficiently full thus not needing to exchange their cargo at the intermediate ports (Ducruet and Notteboom 2012).

In both above-mentioned network types, the trunk line/route dominates regarding its length and intensity of the transported TEU flows. The length is determined by the sea distances between the seaports, which are usually at different continents. In many cases, the intensity of TEU flows justifies more frequent if not even regular use of the large conventional (Panamax Max) and mega (ULC) ships ${ }^{1}$ (Janić 2014; MAN 2009; Rodrigue et al. 2017).

This trunk line/route can be represented as the line with the main end nodes/seaports as its supplier/customer and origin/destination, respectively, of TEU flows as shown on Fig. 3.

In addition, Fig. 3 also shows the ultimate suppliers 'feeding' the supplier seaport and the ultimate customers 'fed' by the customer seaport at both ends of the line/route. The inventories of TEU flows take place at the supplier hub/seaport, the customer hub/seaport, and along the trunk line/route connecting them, the latest during transportation. Consequently, at the supplier hub/seaport, the TEU flows spend some inventory time during collecting, storing, and waiting to be loaded, and loading at the departing ship(s). At 


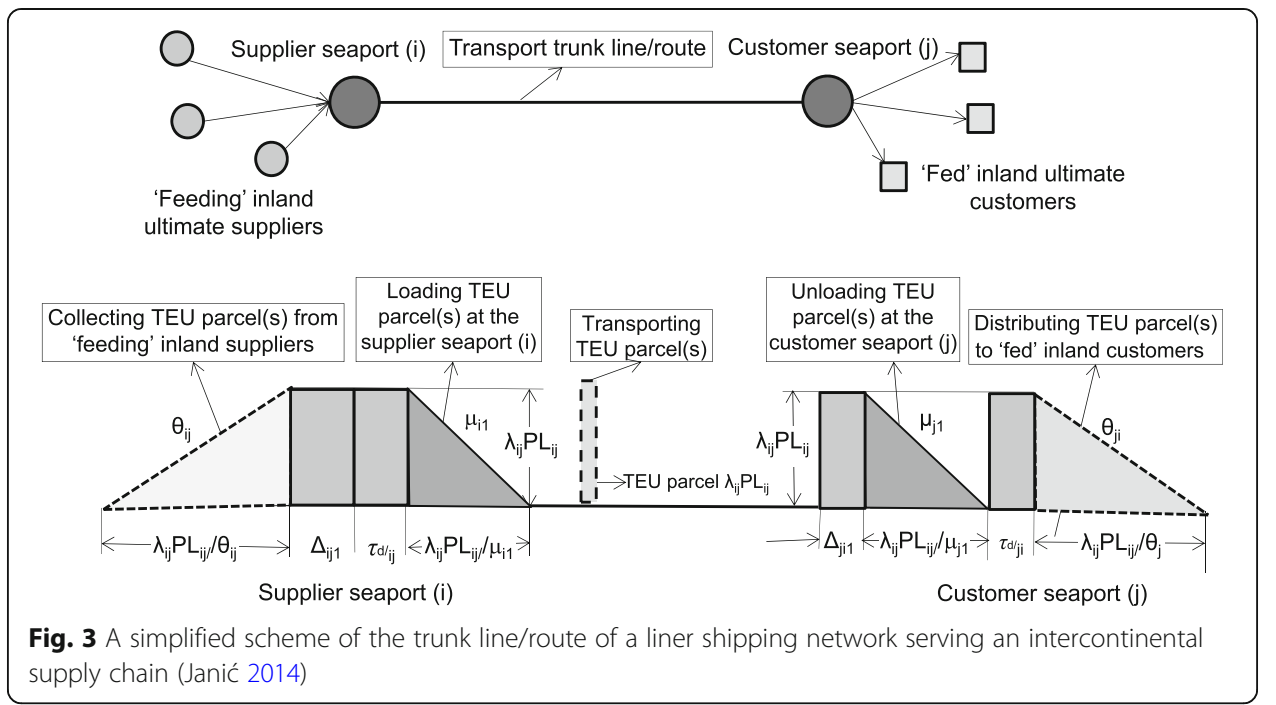

the customer hub/seaport, they spend some time before starting and while being unloaded from the arrived ship(s), during storage, and while being distributed to the ultimate customers. In case of congestion around the seaports and/or irregularities along the route, delays can happened thus extending the TEU flows inventory time at both ports of the line.

\section{Concept of performances}

In general, the performances of a given trunk line/route of the liner container-shipping networks serving the intercontinental supply chains relate to their inherent ability to deliver the given volumes of TEU flows from the supplier (origin) to the customers (destination) hub/seaport under given conditions generally efficiently, effectively, and safely, and at specified price. Similarly as in the other systems, these performances can be classified as infrastructural, technical/technological, operational, economic, environmental, and social. They are inherently interrelated and can generally be in some interaction with each other as shown in Fig. 4 (Janić 2014).

As can be seen, in a "top-down" consideration, the infrastructural performances can generally influence the technical/technological performances, and consequently create a mutual interaction between these and all other performances. In a "bottom-up" consideration, the environmental and social performances can influence the infrastructural and technical/technological performances and consequently create a mutual interaction between these and all other performances.

\section{Modelling the indicators of performances of a trunk line/route of a liner container-shipping network}

An overview of the previous research

A substantial research has been dealing with the analysis and modelling of the liner container shipping networks and intensively published in the dedicated scientific and professional literature. In this rather narrow overview, this research has been broadly classified into three set categories dealing with: a) Analyzing of developments of the 


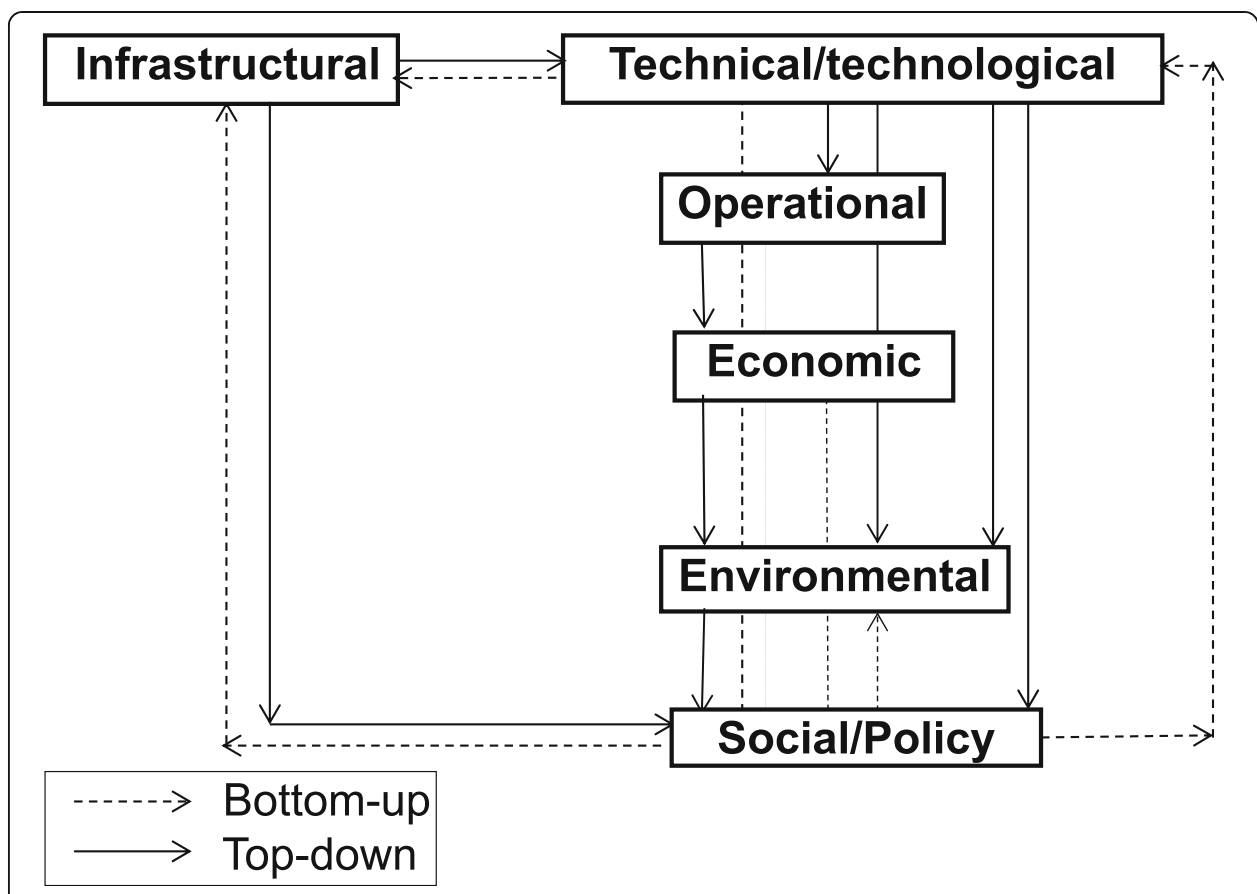

Fig. 4 Scheme of possible classification, potential interrelation and interaction of performances of the maritime part of an intercontinental supply chain (Janić 2014)

liner-shipping container networks including an overview of the research approach; b) Modelling and optimization of the operational and economic performances of the liner shipping networks and their components - nodes (ports) and links (lines/routes) connecting them; c) Design of MPC (Multi-Port-Calling) and H\&S (Hub \& Spoke) shipping networks; and d) The economics and geographical characteristics of the liner container shipping networks. In all considered cases, these networks have consisted of the large seaports connected by the intercontinental shipping lines/routes operated by the container ships of different size and payload capacity including the mega (ULC) ones.

a) The research on analyzing of developments of the liner-shipping container networks and the maritime transport overall from different perspectives including an overview of the research approach has been recently intensified based on the available evidence and data. For example, this has included analysis of development of different types of services provided by the liner shipping networks, proposing a global snapshot of the world-shipping network, and elaborating the interrelationship between developments of the liner shipping networks and the seaports (Ducruet and Notteboom 2012). In some way, this has been complemented by some kind of the multidisciplinary approach towards analyzing the maritime transport including its international and national characteristics, financial performances, skills of workforce involved, position of seaports in transition, logistics, and regulatory framework (Leggate et al. 2012). In addition, more the case-based and focused research has dealt with analyzing the spatial pattern of the China's international shipping network along the so-called "the $21^{\text {st }}$ Century Maritime Silk Road". The attributes considered have been the network growth, hierarchy regarding types of shipping services, and 
phases/milestones of development. The navigational data for the period mid1990s to 2016 has been used. The results have indicated that the spatial expansion of the China's international shipping network has generally been taking place also driven by inclusion of more foreign seaports into the "Maritime Silk Road" network configuration. The role of the large seaports such as Hong Kong and Shanghai in such growing network has also changed including more diversification and consequent managerial implications (Wang et al. 2018). As well, the specific research has been dealing with the research of liner container shipping networks over the period 19672013. The source of information has been 294 papers published in the academic/ scientific journals. The results have indicated the gradual diversification of the research from the prevailing economic consideration at the beginning to the more multi-disciplinary approach also integrating the seaport-related operations and multimodal networks serving the freight/cargo demand door-to-door towards the end of the considered period. Finally, the co-authorship in carrying out this research has been increasing over time although the approach has remained fragmented due to the strong disciplinary specialization (Lau et al. 2018; Wang et al. 2018).

b) Research on modelling, and optimization of the operational and economic performances of the liner shipping networks has generally dealt with explaining the factors influencing growth in the container ship size means by the liner service cash flow model. The results have shown that economies of scale have and will continue to be one of the main driving forces behind deployment of the larger container ships. In addition, the optimal ship size has been dependent of the characteristics of port terminals and trade route(s)/market(s) it has been deployed (Christa et al. 2008). The additional research has investigated viability of the mega-container ships operating in $\mathrm{H} \& \mathrm{~S}$ compared to that of the conventional ships operating in MPC shipping networks by using a non-zero sum two-person game. The results have indicated that the viability of mega container ships operating in the $\mathrm{H} \& \mathrm{~S}$ case-based network(s) has been strongly influenced by the relationships between ship size, the level and structure of costs of ship operator(s), and the freight rate influenced by the market competition (Imai et al. 2006). In addition, estimating the quality of liner shipping operations and particularly those at ports and their container terminals has also been highly on the research agenda. The corresponding research has resulted in developing the methodology based on the measures of the given port's time and cost performances and their balancing indicating the need for eventual investments (in additional berths and/or terminals). The methodology has expected to be useful for the decision/policy makers in the given context (Bassan 2007). As well, the research has been carried out embracing: estimating and modelling possible ways of shortening if not optimizing the door-todoor delivery time of TEU flows - through shortening the ships' sailing and berth time including use of the alternative routes; reducing the container transhipment time by applying different transhipment policies (existing forward and many-to-one and new backward and many-to-one); and through the innovative stacking and reshuffling strategies in the port container terminals. The developed empirical, analytical, and optimization models and their results have been expected to contribute to improvement of the route design, development of ship fleet, 
optimization of sailing speed, and disruption management (Grida et al. 2018). The research results have also indicated potential contribution to reducing the total costs of delivering TEU flows thanks to sailing along the alternative routes (Furuichi and Otsuka 2018), applying innovative transhipment policies (Du et al. 2017) and the innovative stacking and reshuffling strategies of containers (Gharehgozli et al. 2017). These all would substantively reduce the transhipment time of TEU flows and other cargo, in the former case at very low costs, and in the latter case by improving efficiency of handling mega ships at the port container terminals. Last but not least, the most recent research has dealt with different aspects of consideration including predominantly simulation and analytical approach to analyzing and modelling of the national and international maritime transport networks regarding their past and present development, topology and spatial distribution (particularly emergence and strengthening of the global container shipping networks), and influence on the regional development (Ducruet 2018).

c) Research on explicitly design and implicitly optimizing particular performances of MPC and H\&S shipping networks has been rather substantive as pointed out in some overview/review papers (Christiansen et al. 2013; Meng et al. 2014). This research has been roughly categorized into design of the line MPC and H\&S shipping networks. As far as design of the former is concerned, the common objectives have been optimization of the network costs by ship scheduling and goods/freight/cargo routing separately (Agarwal and Ergun 2008) and jointly (Alvarez 2009), including providing an easy access to the sources of data needed for design (Brouer et al. 2014). A mixed-integer programming model and its modifications have been primarily used as the optimization tool. In addition, this has been research on design of the network(s) of liner shipping alliances respecting the costs due to sharing the ship capacities among alliance partners (Agarwal and Ergun 2010; Davison 2014). As well, a design problem of a single line shipping service route including repositioning of empty containers (Shintani et al. 2007; Song and Dong 2013), and compact formulation for the line shipping network design based on service flows (Plum et al. 2014) have been elaborated. In addition to the above-mentioned research by Imai et al. (2006), some research has also dealt with design of the line $H \& S$ shipping networks. This has included a competitive hub location problem for designing the network(s) (Gelareh et al. 2010), analysing the effects of ship fleet deployment on the network design respecting economies of scale in ship size (Gelareh and Pisinger 2011), a design problem with combined MPC and $\mathrm{H} \& \mathrm{~S}$ network while considering empty container repositioning (Meng and Wang 2011), determining the optimal ship routing, size, and sailing frequency for the given $H \& S$ network (Hsu and Hsieh 2007), and design of the H\&S networks by deploying the concept of the main port and few constraints such as the multi-type container shipment and transit time. A mixed-integer programming model with nonconvex multi-linear terms has been developed for the proposed problems and in some cases solved by an efficient genetic algorithm based on a multi-stage decomposition approach (Jianfeng et al. 2015).

d) Research on the economics and geographical characteristics of the liner containershipping networks has been substantive too. For example, one of the most illustrative has provided a review of the characteristics of liner container-shipping 
networks regarding the types of services provided by shipping lines including dynamics of their design and configuration. In addition, a global overview of the world's liner shipping networks based on the ships' movement data and the position of seaports in the liner container-shipping networks regarding to the concept of centrality, hierarchy, and factors of selection have been elaborated (Ducruet and Notteboom 2012). The other has developed the model for predicting container flows round the world along shipping routes passing through 437 container ports and been served by 800 shipping companies. The profit maximization shippers have been assumed to make the route choice. The simple logit model containing the generalized user/shipper costs has been the basis for the route choice model. The generalized cost function has represented the cost of route including the port costs, the cost of transhipment and transport, and the value of transport time. The model has been estimated using the data from different sources/databases. Then, the scenario approach (8 scenarios) has been applied to test sensitivity of throughput of particular ports or transport services provided by shipping lines on the route choice. The results have mainly related to European ports (Tavasszy et al. 2011). As well, the specifically focused research has also investigating the impacts of fuel costs on the design of liner shipping networks. A set of simple analytical models has been developed to estimate: the container ships' turnaround time depending on the length of route, the number and time of port calls, and sailing speed; the threshold route turnaround time depending on the number of deployed ships and transport service frequency; and the minimum required ships' sailing speed needed to operate the liner services under abovementioned conditions - service frequency, the number of port calls, turnaround time, and the size of deployed ship fleet. The models have been applied to the Europe-Far East container-shipping route. The results have indicated the permanent need for balancing between sailing speed, the turnaround time, the number of port calls, size of deployed ship fleet, and finally the overall design and costs of transport services offered to users/shippers shown to be highly dependent on the fuel costs (Notteboom and Vernimmen 2009). In addition, the research analysing the liner container-shipping alliances has been carried out. The three large alliances - Grand Alliance, New World Alliance, and CKYH Alliance have been analysed and compared mainly in terms of 17 indicators of operational performances and motives of shipping carriers to join the alliance depending on its market position in the international/intercontinental shipping markets (Panayides and Wiedmer 2011).

\section{Objectives and assumptions}

This above-mentioned rather narrowly focused literature overview has indicated that there has not been an explicit and straightforward academic and professional research dealing with the multidimensional examination of performances of the trunk lines/routes of liner container-shipping networks serving the intercontinental supply chains by the ships of different size and payload capacity. The present research aims at filling in this gap in some way. Therefore, its objectives are just 
to, according to the concept shown on Fig. 4, perform the multidimensional examination of performances of a trunk line/route of a given liner container-shipping network serving a has implies defining and developing the analytical models of indicators of these performances expected to enable their estimation and carrying out the sensitivity analysis respecting changes of the most influencing factors/variables, in this case the payload capacity and the sailing speed of container ships. Thus, the models of indicators of particular performances of the above-mentioned trunk line/ route are based on the following assumptions (Daganzo 2005; Hall 1993; Janić et al. 1999; Janić 2005):

- The supplier seaport of a given trunk line/route is ultimately the "production location", i.e. origin and the customer seaport is ultimately the "consumption location", i.e., destination, of the given volumes of TEU flows; these can be the main seaports or the hubs of corresponding networks of the liner shipping carriers or their alliances;

- The supplier seaport generates a series of successive "parcels" of the TEU flows to be transported to the customer seaport during the specified period of time exclusively by a given container ship fleet; this implies that, independently of the payload capacity of the ships in the fleet(s), there is always sufficient demand justifying always economically feasible direct and reasonably frequent transport services along the trunk line/route connecting its two end seaports; and vice versa, there is always the sufficient ship fleet capacity offered to satisfy the generated volumes of TEU flows;

- The size (volume, weight) of a single "parcel" of TEU flows is always less than or at most equal to the corresponding payload capacity of a deployed $\operatorname{ship}(\mathrm{s})$;

- The container ship fleet consisting of the ships of same size, payload capacity, and approximately the same average load factor perform direct liner shipping ${ }^{2}$ between the supplier and the customer seaport without the multi-port calling;

- The indicators of infrastructural and technical/technological performances of the trunk line/route are considered as inputs for the models of its operational, economic, environmental, and social performances; and

- The exclusive use of a given ship fleet along the given trunk line/route implies "all-or-nothing principle" of transporting the given volumes of TEU flows under given conditions.

\section{Structure of the models}

\section{Infrastructural performances and technical/technological performances}

The infrastructural performances relate to the physical/spatial characteristics of the seaports and their container terminals at both ends of the given trunk line/route. These are the number and size of the berths to handle particular categories of ships and the size and capacity of the container terminals handling and storing the TEU flows. The indicators of these performances are not particularly modelled but assumed as given for modelling the indicators of the operational, economic, environmental, and social performances. 
The technical/technological performances reflect the characteristics of the containers ships operating along the given trunk line/route. These are dimension (length, beam, height, and draft), payload capacity, and the number of engines and their power. In addition, these are the capacity of facilities and equipment for loading/unloading (cranes) and storing (dedicated space/depots at the container terminals) TEU flows at the seaports before and after their transportation along the given trunk line/route of the network. Similarly as at the infrastructural performances, their indicators are not particularly modelled but assumed as given for modelling the indicators of the operational, economic, environmental, and social performances.

\section{Operational performances}

The operational performances relate the volumes of TEU flows to be transported along the given trunk line/line during a given period of time; the frequency of transport services based on the size of parcels of TEU flows taken per service frequency; the required container ship fleet (i.e. the type and number of ships deployed); and the ship fleet's transport work and technical productivity - all under given conditions. Therefore, the indicators of operational performances of the given trunk line/route are considered to be: i) Transport service frequency; ii) Size of ship fleet; iii) Transport work; and iv) Technical productivity.

\section{i) Transport service frequency $(\operatorname{dep} / \tau)$ :}

The transport service frequency can be set up either to serve the given volumes of TEU flows or enable the regular scheduled transport services during the given time.

a) Serving the given volumes of TEU flows in the single direction:

$$
f_{i j}(\tau)=\frac{Q_{i j}(\tau)}{\lambda_{i j} \cdot P L_{i j}}
$$

b) Enabling the regular scheduled transport services in the single direction during the given time:

$$
f_{i j}^{*}(\tau)=\frac{\tau}{h_{i j}(\tau)}
$$

From Eq. 2, if the ship's payload per frequency is considered as a TEU parcel, the total volumes of TEU flows, which can be transported during the given time, is estimated as: 


$$
Q_{i j}^{*}(\tau)=\beta_{i j}(\tau) \cdot\left[\min \left(f_{i j}(\tau) ; f_{i j}^{*}(\tau)\right)\right] \cdot\left(\lambda_{i j} \cdot P L_{i j}\right)
$$

\section{ii) Size of ship fleet (the number of deployed ships)}

The size of ship fleet, i.e., the number of ships deployed along the given trunk line during the given time is estimated as follows:

$$
N_{i j}(\tau)=\beta_{i j}(\tau) \cdot\left[\min \left(f_{i j}(\tau) ; f_{i j}^{*}(\tau)\right)\right] \cdot\left[t_{i j}\left(d_{i j}\right)\right]
$$

If each ship operates along the line/route in both directions at the approximately same load factor, the average ship's turnaround time $\left[t_{i j}\left(d_{i j}\right)\right]$ in Eq. 4 is estimated as follows:

$$
\begin{aligned}
t_{i j}\left(d_{i j}\right)=\tau_{i j} & +\tau_{j i}=\Delta_{i j / 1}+\frac{\lambda_{i j} \cdot P L_{i j}}{u_{i 1} \cdot \mu_{i 1}}+D_{d i}+\frac{d_{i j}}{\left[s_{i j} \cdot v_{i j}\left(d_{i j}\right)\right]}+D_{i j}+D_{a j}+\Delta_{j i / 1} \\
& +\frac{\lambda_{i j} \cdot P L_{i j}}{u_{j 1} \cdot \mu_{j 1}}+\quad+D_{d j}+\Delta_{j i}\left(\xi_{j}\right)+\frac{\lambda_{j i} \cdot P L_{i j}}{u_{j 2} \cdot \mu_{j 2}}+\frac{d_{j i}}{\left[s_{j i} \cdot v_{j i}\left(d_{j i}\right)\right]}+D_{j i} \\
& +D_{a i}+\Delta_{i j / 2}+\frac{\lambda_{j i} \cdot P L_{i j}}{u_{i 2} \cdot \mu_{i 2}}
\end{aligned}
$$

\section{iii) Transport work (TEU-km/t)}

The transport work is the product between the total number of transported TEU parcels during the given time $(\tau)$, i.e., transport service frequency, and the corresponding distance. It is estimated as follows:

$$
T W_{i j}(\tau)=\beta_{i j}(\tau) \cdot\left[\min \left(f_{i j}(\tau) ; f_{i j}^{*}(\tau)\right)\right] \cdot\left(\lambda_{i j} \cdot P L_{i j}\right) \cdot d_{i j}
$$

iv) Technical productivity (TEU / $\mathbf{\tau}^{2}$ ).

The technical productivity is the product between the total number of transported TEU parcels during the given time, transport service frequency, and the speed of their delivery throughout the chain. It is estimated as follows:

$$
\operatorname{TPC}_{i j}(\tau)=\beta_{i j}(\tau) \cdot\left[\min \left(f_{i j}(\tau) ; f_{i j}^{*}(\tau)\right)\right] \cdot\left(\lambda_{i j} \cdot P L_{i j}\right) \cdot\left(d_{i j} / \tau_{i j}\right)
$$

Where.

$\tau$ is the given time (day, week, year);

$T U$ is the time unit (h, day);

$Q_{i j}(\tau)$ is the volume of TEU flows to be transported from the supplier seaport (i) to the customer seaport $(j)$ of the trunk line/route during time $(\tau)(\mathrm{TEU} / \tau)$; 
$\lambda_{i j}, P L_{i j}$ is the average load factor and the payload capacity, respectively, of a ship serving the line/route $(i j)$ (the product of both is considered as a TEU parcel $\left(\lambda_{i j} \leq 1.0\right)$ (-; TEU/ship);

$h_{i j}(\tau)$ is the average time between scheduling the regular transport services between the supplier seaport (i) and the customer seaport (j) during time ( $\tau$ ), (TU/dep);

$\beta_{i j}(\tau)$ is the proportion of planned/scheduled transport services realized between the supplier seaport (i) and the customer seaport $(j)$ during time $(\tau)\left(\beta_{i j}(\tau) \leq 1.0\right)(-)$;

$\tau_{i j} \quad \tau_{j i}$ is the average sailing time of a ship between the supplier seaport (i) and the customer seaport ( $j$ ), and vice versa, respectively (TU/ship);

$\Delta_{i j / 1}, \Delta_{j i / 1}$ is the time before starting loading a TEU parcel at the supplier seaport (i) for the customer seaport ( $j$ ) and before its unloading at the customer seaport ( $j$ ) after arrived from the supplier seaport (i), respectively (TU);

$\Delta_{j i / 2}, \Delta_{i j / 2}$ is the time before starting loading a TEU parcel at the customer seaport (j) for the supplier seaport (i) and before its unloading at the supplier seaport (i) after arrived from the customer seaport (j), respectively (TU);

$d_{i j}$, $d_{j i}$ is the length of trunk line/route, i.e., the sailing distance between the supplier seaport $(i)$ and the customer seaport (j), and vice versa, respectively $(\mathrm{nm})(\mathrm{nm}$ - nautical mile; $1 \mathrm{~nm}=1.852 \mathrm{~km})$;

$v_{i j}\left(d_{i j}\right), v_{j i}\left(d_{j i}\right)$ is the average (planned) ship's steaming speed on the line/route $\left(d_{i j}\right)$ and $\left(d_{j i}\right)$, respectively (kts) (kt - knot; h - hour; $1 \mathrm{kt}=1 \mathrm{~nm} / \mathrm{h}$ );

$D_{d i}, D_{a j} D_{d j}, D_{a i}$ is the average departure delay of a given transport service in the supplier seaport (i) and the average arriving delay at the customer seaport (j), respectively, and vice versa, (TU/ship);

$D_{i j}$, $D_{j i}$ is the average delay per transport service along the trunk line/route between the supplier seaport (i) and the customer seaport (j), and back, respectively (TU/ship);

$\mu_{i 1}, \mu_{j 1}$ is the capacity of loading and unloading ships at the supplier seaport (i) and the customer seaport (j), respectively (TEU/TU);

$u_{i 1}, u_{j 1}$ is the proportion of used loading and unloading capacity at the supplier seaport (i) and at the customer seaport ( $j)$, respectively $(\leq 1.0)$;

$\mu_{j 2}, \mu_{i 2}$ is the loading and unloading capacity of ships at the customer seaport ( $j$ ) and at the supplier seaport (i), respectively (TEU/TU);

$u_{j 2}, u_{i 2}$ is the proportion of used loading and unloading capacity at the customer seaport (j) and the supplier seaport (i), respectively ( $\leq 1.0)$; and.

$s_{i j}, s_{j i}$ is the portion of maintained average ship's planned operating speed under given operating conditions along the trunk line/route $\left(d_{i j}\right)$ and $\left(d_{j i}\right)$, respectively $\left(s_{i j}, s_{j i} \leq 1.0\right)(-)$.

In Eq. 1 (a-d), the loading and unloading capacity of a ship at the supplier and/or the customer seaport $(i)$ and $(j)$ is estimated as follows:

$$
\mu_{i / j / 1 / 2}=n_{c / i / j} \cdot m_{c / i / j} \cdot k_{i / j} \cdot \rho_{c / i / j}
$$

Where.

$n_{c / i / j}$ is the number of cranes per berth in the seaport (i) and/or in the seaport (j) (units/berth);

$m_{c / i / j}$ is the loading/unloading rate, i.e., the number of moves per crane per unit of time in the seaport ( $i$ ) and/or in the seaport (j) (moves/h);

$k_{i / j}$ is the TEU-factor ${ }^{3}$ in the seaport (i) and/or in the seaport (j) (-);

$\rho_{c / / / j}$ is the average crane utilization rate in the seaport $(i)$ and/or in the seaport $(j)(\leq 1.0)$; 


\section{Economic performances}

The economic performances generally relate to the total and the average inventory, handling, transport, and the external costs (externalities) along the given trunk line/ route under given conditions. Therefore, the considered indicators of economic performances are: i) Inventory; ii) Handling; iii) Transport; iv) External; and v) Total costs, of a given TEU parcel transported along the given trunk line/route, estimated as follows:

\section{Inventory costs (\$US)}

$$
\begin{gathered}
C_{i j / I N V}\left(\lambda_{i j}, P L_{i j}\right)=I T_{i}\left(\lambda_{i j}, P L_{i j}\right) \\
\cdot \alpha_{i}+\left(\lambda_{i j} \cdot P L_{i j}\right) \cdot\left(\frac{d_{i j}}{s_{i j} \cdot v_{i j}\left(d_{i j}\right)}+D_{i j}\right) \cdot \alpha_{i j}+ \\
+I T_{j}\left(\lambda_{i j}, P L_{i j}\right) \cdot \alpha_{j}
\end{gathered}
$$

The first and the third term in Eq. 9 represent the inventory costs of a TEU parcel at the supplier seaport ( $i$ ) and at the customer seaport (j), respectively. The second term represents the inventory, i.e., the cost of time of a TEU parcel while being in transportation between the seaports $(i)$ and (j). From Fig. 3, the inventory time of a TEU parcel $\left(\lambda_{i j} P L_{i j}\right)$ at the seaport $(i)$ before being sent to the seaport $(j)$ is estimated as follows:

$$
I T_{i}\left(\lambda_{i j}, P L_{i j}\right)=\frac{1}{2} \cdot\left(\lambda_{i j} \cdot P L_{i j}\right)^{2} \cdot\left(\frac{1}{\theta_{i j}}+\frac{1}{u_{i 1} \cdot \mu_{i 1}}\right)+\left(\lambda_{i j} \cdot P L_{i j}\right) \cdot\left(\bar{\tau}_{d / i j}+\Delta_{i j / 1}+D_{d i}\right)
$$

Similarly, the inventory time of a TEU parcel $\left(\lambda_{i j} P L_{i j}\right)$ at the seaport $(j)$ after arrived from the seaport $(i)$ is estimated as follows:

$$
I T_{j}\left(\lambda_{i j}, P L_{i j}\right)=\frac{1}{2} \cdot\left(\lambda_{i j} \cdot P L_{i j}\right)^{2} \cdot\left(\frac{1}{u_{j 1} \cdot \mu_{j 1}}+\frac{1}{\theta_{j i}}\right)+\left(\lambda_{i j} \cdot P L_{i j}\right) \cdot\left(D_{a j}+\Delta_{j i / 1}+\bar{\tau}_{d / j i}\right)
$$

\section{ii)/iii) Handling and transport costs (SUS)}

The handling and transport costs of a TEU parcel include those of handling it at the supplier seaport (i) and at the customer seaport ( $j)$, and transporting between these seaports as follows:

$$
C_{i j / T R A}\left(\lambda_{i j}, P L_{i j}\right)=\left(\lambda_{i j} \cdot P L_{i j}\right) \cdot\left[c_{i}+c_{i j}\left(\lambda_{i j}, P L_{i j}\right) \cdot\left(\frac{d_{i j}}{s_{i j} \cdot v_{i j}\left(d_{i j}\right)}\right)+c_{j}\right]
$$


The externalities are expressed in terms of the cost of emitted GHG from the fuel consumption as follows:

$$
C_{i j / e}\left(\lambda_{i j}, P L_{i j}\right)=\left\{F C\left[P L_{i j} ; v_{i j}\left(d_{i j}\right)\right] \cdot \sum_{k=1}^{K} e_{k} \cdot C_{C O_{2}}\right\} \cdot\left(\lambda_{i j} \cdot P L_{i j}\right)
$$

\section{v) Total costs (\$US)}

The total costs are estimated as the sum of inventory, handling, transport, and external costs as follows:

$$
C_{i j}\left(\lambda_{i j}, P L_{i j}\right)=C_{i j / I N V}\left(\lambda_{i j}, P L_{i j}\right)+C_{i j / T R A}\left(\lambda_{\mathrm{i} j}, P L_{i j}\right)+C_{i j / e}\left(\lambda_{i j}, P L_{i j}\right)
$$

Where.

$\theta_{i j}, \theta_{j i}$ is the intensity of collecting and distributing the TEU parcels at the supplier seaport (i) and the customer seaport ( $j$ ), respectively (TEU/TU) (TU $\equiv$ day);

$c_{i} c_{j}$ is the average handling (loading/unloading/transhipment/storage) cost of a TEU parcel at the supplier seaport ( $i$ ) and the customer seaport ( $j$ ), respectively (\$US/TEU);

$c_{i j}\left(\lambda_{i j}, P L_{i j}\right)$ is the average transport cost of a TEU parcel between the seaports $(i)$ and (j) (\$US/(TEU-day);

$\alpha_{i} \alpha_{i j} \alpha_{j}$ is the cost of a TEU parcel inventory time while at the supplier seaport (i), in transportation, and at the customer seaport (j), respectively (\$US/TEU-TU).

$\bar{\tau}_{d / i j}, \bar{\tau}_{d / j i}$ is the average dwell time of a TEU parcel at the container terminal of the supplier seaport (i) before being sent to the customer seaport $(j)$ and at the customer port (j) before being distributed to the ultimate customers, respectively (TU/TEU).

$F C\left[P L_{i j}, v_{i j}\left(d_{i j}\right)\right]$ is the average fuel consumption by a container ship of the payload capacity $\left(P L_{i j j}\right)$ operating along the trunk line/route $\left(d_{i j}\right)$ at the steaming speed $\left[v_{i j}\left(d_{i j}\right)\right]$ (tons/day);

$e_{k}$ is the emission rate of the ( $k$ )-th GHG from the fuel consumed by the container ship operating along the trunk line/route $\left(d_{i j}\right)$ (ton of GHG/ton of fuel); and.

$K$ is the number of various GHG emitted from the fuel consumed by the container ships operating along the trunk line/route $\left(d_{i j}\right)$; and.

$\mathrm{C}_{\mathrm{CO}_{2}}$ is the average social cost of emissions of GHG $\left(\mathrm{CO}_{2}\right)$ (\$US/ton).

The other symbols are analogous to those in Eq. 1 (a, b, c, d).

The average transport costs $\left[c_{i j}\left(\lambda i j, P L_{i j}\right)\right]$ in Eq. 12 consist of the main components approximately including the ship's: i) Fixed depreciation and insurance costs; ii) Fuel costs; and iii) Operational costs (crew, insurance, stores and lubes repairs and maintenance $^{4}$ (Christa et al. 2008; Drewry 2017; UNCTAD 2017). By replacing the size of a TEU parcel $\left(\lambda_{i j} P L_{i j}\right)$ by the volumes of TEU flows generated during time $(\tau)\left[Q_{i j}(\tau)+\right.$ $\left.Q_{j i}(\tau)\right]$, the corresponding indicators of economic performances can be estimated from Eq. 2 (a, b, c, d, e, f). 


\section{Environmental performances}

The environmental performances relate to the energy (fuel) consumption and the consequent direct and indirect emissions of GHG (Green House Gases) by the ships performing transport services and the area of land used by the trunk line/route infrastructure, in this case parts of the seaports and their container terminals enabling handling both ships and their payload (TEU parcels). Therefore, the indicators of environmental performances are considered to be: i) The ships' fuel consumption and related emissions of GHG (Green House Gases); and ii) The land used. The ships' and seaports' waste and used water also having an impact on the environment are not considered.

\section{i) Fuel consumption and emissions of GHG (Green House Gases) (tons)}

- The average fuel consumption (ton/TEU-day) by ships sailing along the given trunk line/route between the seaport $(i)$ and the seaport $(j)$ is estimated as follows (tons/day:

$$
F C_{i j}\left(\lambda_{i j}, P L_{i j}\right)=F C\left[P L_{i j} ; v_{i j}\left(d_{i j}\right)\right] /\left(\lambda_{i j} \cdot P L_{i j}\right)
$$

And

- The corresponding average emissions of GHG ( $\mathrm{kgCO}_{2} / \mathrm{TEU}$-day) are estimated as follows:

$$
E M_{i j}\left(\lambda_{i j}, P L_{i j}\right)=F C_{i j}\left(\lambda_{i j} \cdot P L_{i j}\right) \cdot \sum_{k=1}^{K} e_{k}
$$

Where all symbols are as in the previous Equations.

By combining Eqs. 5, 15, and 16, the corresponding total amounts can be estimated for the trunk line/route under given conditions.

\section{ii) Land use}

Container ships are handled at the berths (port's seaside area) facing the seaport container terminals, which indirectly or directly occupy the land on the shore (landside). This area of land used by these terminals generally includes: i) The apron area; ii) The container storage and transfer area; and iii) The area for different buildings (container freight station, offices, workshops, etc.) (Gharehgozli et al. 2016; Ligteringen and Veslsink 2012). The areas of land used for the apron and the container storage are only estimated.

- Berth area 
The land used for the berth area in the supplier seaport (i) and/or in the consumer seaport $(j)$ is estimated as follows:

$$
L U_{b a / i / j}=L_{q / i / j} \cdot S_{i / j}
$$

Where.

$L_{q / i / j}$ is the length of quay along the berths in the seaport (i) and/or in the seaport ( $j$ ) (m); and.

$S_{i / j}$ is the width of a berth as the right-angle distance between the waterfront and the line of the storage yard in the seaport (i) and/or in the seaport (j) (m).

The length of quay $\left(L_{q / i / j}\right)$ in Eq. 17 is estimated as follows (Ligteringen and Veslsink 2012):

$$
\begin{aligned}
L_{q / i / j}=\left\{L_{s / \max }+2 \cdot 15, \text { for } n_{b / i / j}=1\right\} \\
\left\{1.1 \cdot N_{b / i / j} \cdot\left(\overline{L_{s}}+15\right)+15, \text { for } n_{b / i / j}>1\right\}
\end{aligned}
$$

Where.

$L_{s / \max }, \bar{L}_{s}$ is length of the largest and the average ship, respectively, using a single and few berths, respectively, in any seaport ( $\mathrm{m})$; and.

$N_{b / i / j}$ is the number of berths in the seaport (i) and/or the seaport (j) intended to the container ships operating along the given trunk line/route (ij) (-).

The number of berths $\left(N_{b / i / j}\right)$ in Eq. 18 is estimated based on Eq. 8 as follows:

$$
N_{b / i / j}=\frac{Q_{i j}(\tau)+Q_{j i}(\tau)}{\mu_{i / j / 1 / 2} \cdot n_{h / i / j} \cdot n_{d y r / i / j} \cdot \rho_{b / i / j}}
$$

Where.

$n_{h / i / j}$ is the berth's operational time during the day in the seaport (i) and/or in the seaport (j) (h/TU) (h - hour; $\mathrm{TU} \equiv$ day);

$n_{d y r / i / j}$ is the berth's operation time during the year in the seaport $(i)$ and/or in the seaport $(j)(\mathrm{TU} / \tau)$ (TU $\equiv$ day; $\tau \equiv$ year); and.

$\rho_{b / i / j}$ is the average utilization rate of berths in the seaport (i) and/or in the seaport ( $\left.j\right)$ $(\leq 1.0)$.

The other symbols are analogous to those in the previous Equations.

\section{- Container storage area}

The land used for storing containers in the container terminals at the seaport (i) and/ or the seaport (j) can be estimated as follows (Ligteringen and Veslsink 2012):

$$
L U_{c s / i / j}=\frac{\left[Q_{i j}(\tau)+Q_{j i}(\tau)\right] \cdot \bar{t}_{d / i / j} \cdot A_{T E U / i / j}}{n_{c t s / i / j} \cdot n_{c t / d y r / i / j} \cdot \rho_{c t / i / j}}
$$

$A_{T E U / / / j}$ is the area occupied by a container in the container terminal of the seaport (i) and/or the seaport (j) $\left(\mathrm{m}^{2} / \mathrm{TEU}\right)$; 
$n_{c t s / i j j}$ is the stacking height of containers in the container terminal of the seaport (i) and/or the seaport (j) (-); and.

$\rho_{c t / i / j}$ is the average utilization of the available space in the container terminal(s) of the seaport (i) and/or the seaport $(j)(\leq 1.0)$.

The other symbols are analogous to those in the previous Equations.

- "Total" land used

The "total" land used for berths and storage areas of the container terminals at the seaport (i) or the seaport (j) can be estimated by Eqs. 17 and 19 as follows:

$$
L U_{T O T / i / j}=L U_{b a / i / j}+L U_{c s / i / j}
$$

Where all symbols are as in the previous Eqs.

This area of land used does not include that for transferring containers between the storage yard and the inland transport modes (road and rail), and that for different buildings (container freight station, offices, workshops, etc.).

\section{Social performances}

The social performances relate exclusively to the impacts of the given trunk line/route on the society, i.e., population, such as generally noise, congestion, and the safety of operations. The excessive noise generated by delivering the TEU flows between the ultimate suppliers and customers to/from the corresponding seaports by the inland transport modes and their systems can burden the neighbouring population. At the same time, congestion and delays can also occur at these modes and systems. In addition, some congestion and delays can also occur in handling ships at the line's seaports. The safety of operations implies an inherent risk of losing ships, their payload, and lives of staff due to the traffic incidents/accidents happening at the seaports and along the trunk line/route connecting them. Consequently, the indicators of social performances considered to relate exclusively to its impacts are: i) Noise; ii) Congestion; and iii) Traffic incidents/accidents (i.e., Safety) (Janić, 2014). At the given trunk line/ route, the exclusively considered relevant impacts are congestion and traffic incidents/ accidents (i.e., safety). The effects such as its contribution to the GDP (Gross Domestic Product), employment, profitability of the particular main actors/stakeholders involved (shipping companies, ports, inland freight transport operators, etc.) are not considered.

\section{i) Congestion and delays.}

The congestion and delays of the liner container-shipping services can happen around the supplier and the consumer seaports due to many reasons. At the supplier seaport, particular departing ships can be delayed generally due to unplanned insufficiency of their loading capacity. At the consumer seaport, the container ships performing scheduled regular services have been given in advance the time slots for entry and using the infrastructure (berths and container terminals). They can be handled without substantive delays before entry if arrive at the seaport almost close or exactly within the assigned time slots and if the already served ships leave the seaport according to the planned schedule implying freeing its capacity for handling the new comers. However, if there is stochasticity/irregularity in both processes the arriving ships can be 
imposed delays before entering or leaving the given seaport. For example, from G/G/N queuing system model, the average waiting/delay and the total time of a ship arriving at the customer seaport of a given line/route is estimated as follows (Ligteringen and Veslsink 2014):

$$
\bar{D}_{q} \approx \frac{\lambda \cdot\left(\sigma_{X}^{2}+\sigma_{S}^{2} / N_{b}\right)}{2\left(1-\lambda / N_{b} \cdot \mu\right)} \text { and } \bar{D} \approx \frac{1}{N_{b} \mu}+\frac{\lambda \cdot\left(\sigma_{X}^{2}+\sigma_{S}^{2} / N_{b}\right)}{2\left(1-\lambda / N_{b} \cdot \mu\right)}
$$

Where.

$\lambda$ is the intensity of arriving ships at the customer seaport (ships/day or week) $(\lambda=1$ / $\left.h_{a}\right)\left(h_{a}\right.$ - is the average inter-arrival time (TU/ship; TU $\equiv$ days or weeks);

$\mu$ is the capacity of a single berth (ships/day or a week) $\left(\mu=1 / \tau_{d}\right)\left(\tau_{d}\right.$ - is the average service time of a ship at the berth (TU/ship));

$N_{b}$ is the number of free berths for handling the arriving ships; and.

$\sigma_{X}, \sigma_{S}$ is the standard deviation of the probability distribution of the arrival times and the service times of arriving ships, respectively (TU/ship).

As can be seen, the ship's average waiting time increases more than proportionally with increasing of the berths' utilization rate $\left[\rho=\lambda /\left(N_{b} \cdot \mu\right)\right]$, thus implying keeping this utilization rate rather low in order to reduce the ships' delays before entering or leaving the port, and vice versa.

ii) Safety.

The safety can be expressed by the number of expected or potential losses of container ships while operating along the given trunk line/route during time $(\tau)$ as as follows:

$$
n_{S L / i j}(\tau)=p \cdot\left[Q_{i j}(\tau)+Q_{j i}(\tau)\right] \cdot d_{i j}
$$

Where.

$p$ is the average rate of accidents/losses of container ships during time ( $\tau$ ) (number/ TEU-mile).

The other symbols are analogous to those in the previous Equations.

\section{An application of the models of indicators of performances: The trunk line/ route between far East Asia and North Europe}

The case

The above-mentioned models of indicators of performances have been applied to the trunk line/route spreading between Far East Asia and North Europe operated by the liner container shipping carriers. In the East-West direction, the supplier of TEU flows has considered to be the port of Hong Kong (International Terminals) (Hong Kong, China) and the customer the port of Rotterdam (APM Terminals) (Rotterdam, The Netherlands). In the West-East direction, the roles of these ports are opposite. The sailing distance between two ports through Suez Channel is $9748 \mathrm{~nm}(1 \mathrm{~nm}=1.852 \mathrm{~km})$ (http://www.sea-distances.org/). Currently, this is one of the world's busiest sea shipping routes/markets ${ }^{5}$ of the type line bundling service whose scheme is shown on Fig. 5 (Ducruet and Notteboom 2012). 


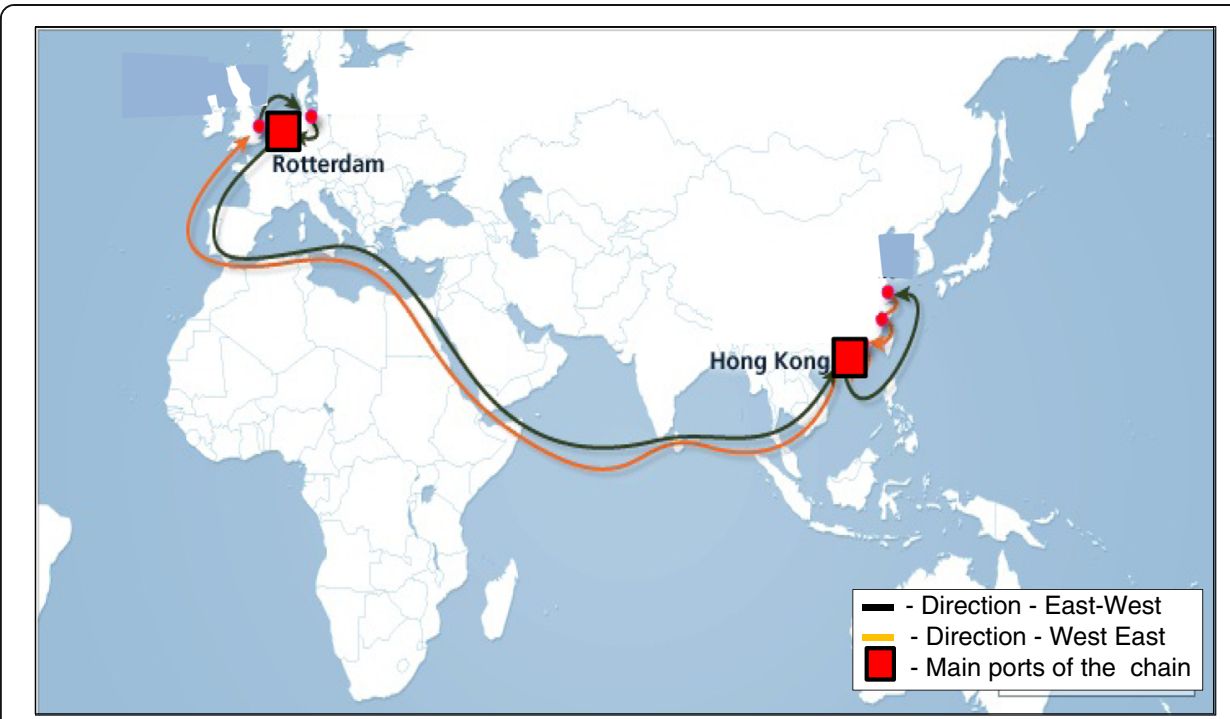

Fig. 5 Spatial/geographical layout of the trunk line/route of line container shipping network: Hong KongRotterdam-Hon Kong (Ducruet and Notteboom 2012; http://www.ship.gr/news6/hanjin28.htm)

In addition, Fig. 6 shows development of the container flows in both directions on 22 Asia-Europe-Asia shipping trunk lines/routes/markets served by 4 major global line shipping alliances. The line/route between Far East and North Europe shared about 70\% of this total, and the line/route Hong Kong-Rotterdam-Hong Kong about 15\% of the latest amount (GSF 2016; Panayides and Wiedmer 2011).

The container terminals at both seaports and the characteristics of trunk line/route enable access and operations of both conventional and mega (ULC) ships (Water depth in the Rotterdam port is $24 \mathrm{~m}$, in Suez Cannel $24 \mathrm{~m}$, and in the Hong Kong port $17 \mathrm{~m}$ ) (Dynamar 2015; HKMPB 2017; PoR 2015). Collection and distribution of the TEU parcels from the ultimate suppliers and the ultimate customers, respectively, at both seaports has been carried out by the rail/intermodal, road, inland waterway (barge), and feeder (including short-sea) shipping transport services (Zhang et al. 2009). In this case, it is assumed that two categories of container ships have exclusively served the given chain: the conventional (Panamax Max) and the mega or ULC (Triple E Maersk), the latter introduced in the year 2013. Some of their technical/technological performances specified by design are shown on Fig. 7 (AECOM 2012; Rodrigue et al. 2017).

\section{Input data}

The scenarios of operating the given trunk line/route by exclusive use of the above-mentioned categories of container ships have implied their operating at the typical slow steaming (20kts) and the supper slow steaming ( $15 \mathrm{kts})$ speed $(1 \mathrm{kt}=1 \mathrm{~nm} / \mathrm{h}$; nm - nautical mile) (Ferrari et al. 2015; SCG 2013). In addition, only direct transportation of the TEU parcels in the single East-West (i.e., Hong Kong-Rotterdam) direction has been considered, i.e. as mentioned above, without the intermediate port calls. Due to the specifics of the case, the indicator of social performances such as noise has not been considered. 


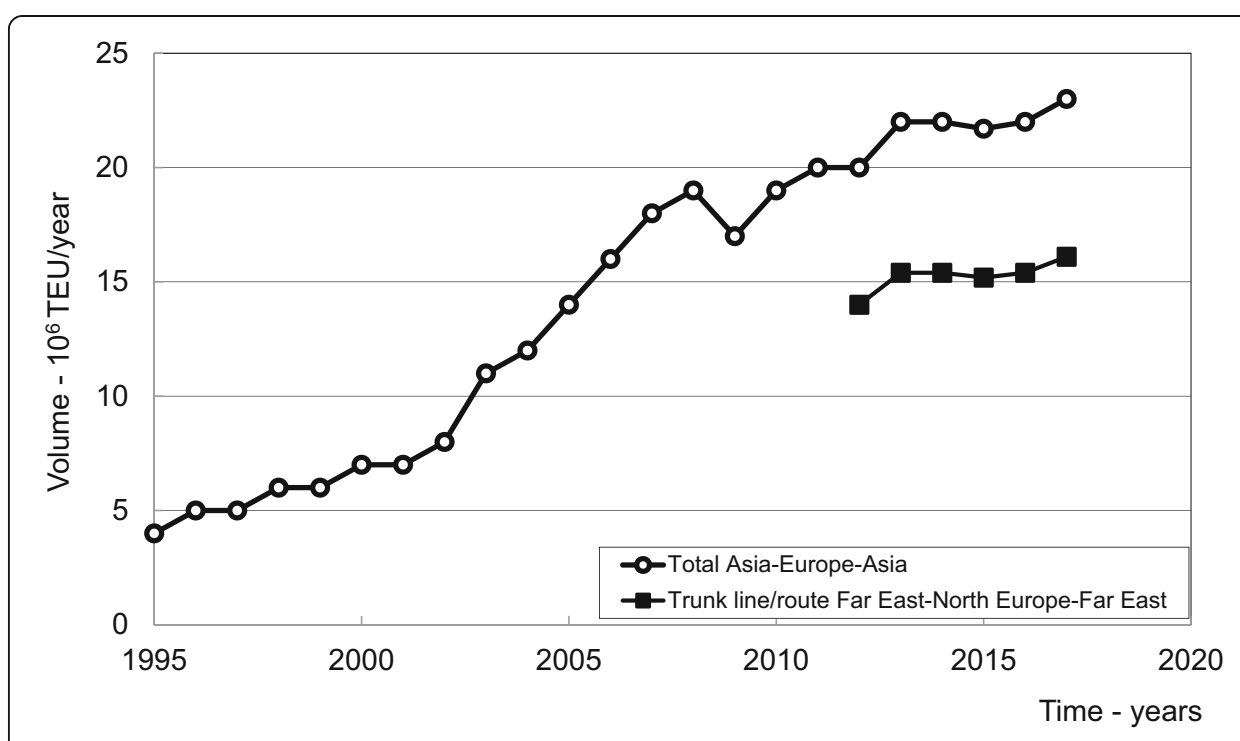

Fig. 6 Development of the sea shipping container flows in the Asia-Europe-Asia sea shipping market over time (UNCTAD 2017)

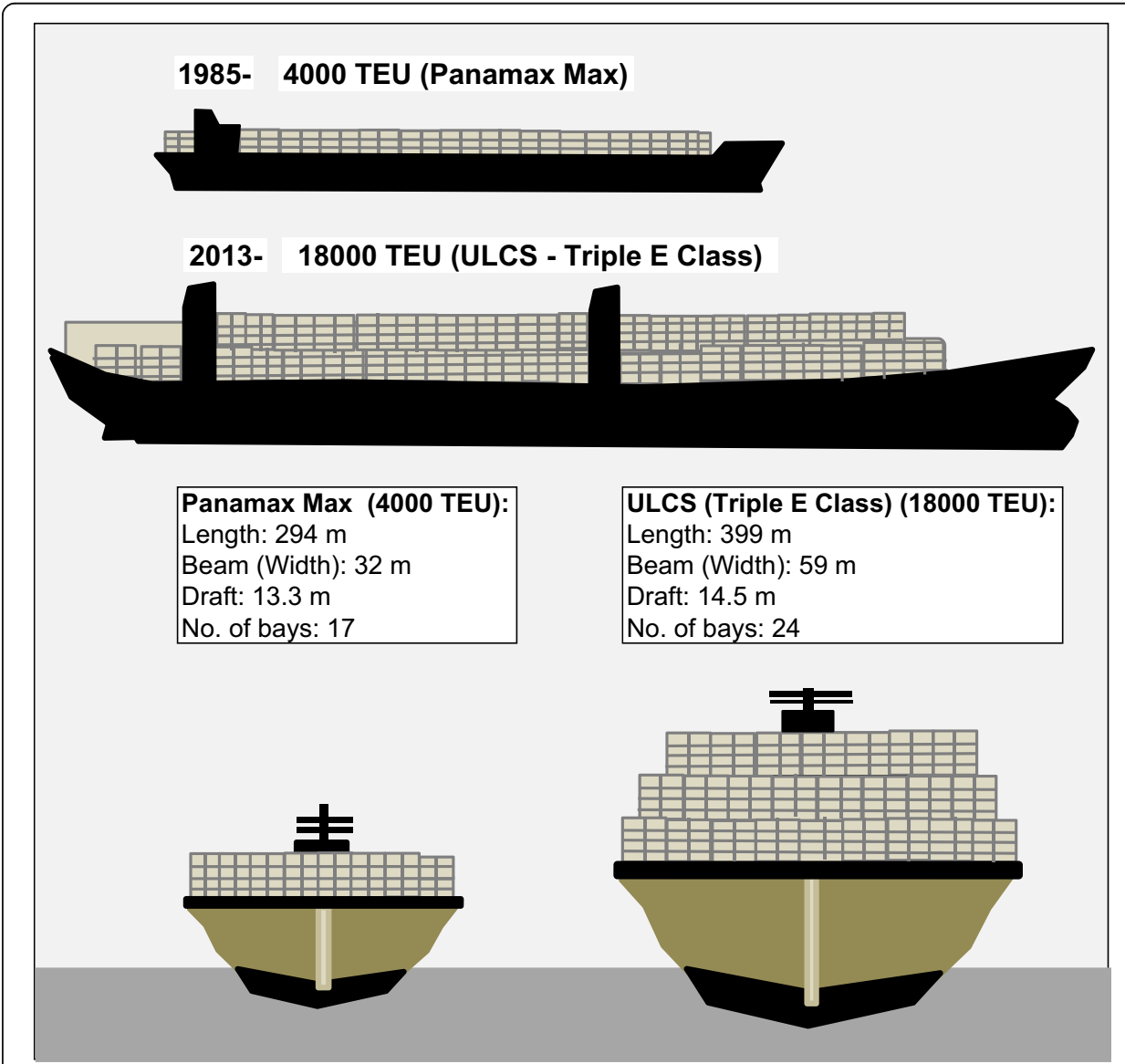

Fig. 7 Overview of the scale of container ships used along the given line shipping trunk line/route (AECOM 2012; Rodrigue et al. 2017; PR 2011) 
The input data for application of the proposed models of indicators of performances of the trunk line/route under given conditions have been collected from the case itself as well as from the other secondary sources. They are given in Table 1.

The transport service frequency per direction has been estimated by using the required annual volumes of TEU flows per direction, the ship payload capacity, and an initial load factor of: $\lambda_{i j}=0.70$ for the conventional and $\lambda_{i j}=0.90$ for the mega or ULC ships. This has given the transport service frequency per direction of:

$f_{i j}[2,433,543 /(4000 \cdot 0.70)] / 52 / 2=8.36 \mathrm{dep} /$ week for the former and. $f_{i j}[2,433,543 /(18,000 \cdot 0.90)] / 52 / 2=1.44 \mathrm{dep} /$ week for the latter category of ships.

After rounding the weekly service frequency to: $f_{i j}=8 \mathrm{dep} /$ week for the conventional and: $f_{i j}=2 \mathrm{dep} /$ week for the mega (ULC) ships, the corresponding load factors have returned to be: $\left.\lambda_{i j} 2,433,543 /(4000 \cdot 8)\right] / 52 / 2=0.73$ for the former, and.

$\left.\lambda_{i j} 2,433,543 /(18,000 \cdot 2)\right] / 52 / 2=0.65$ for the latter ship fleet.

This implies that the average size of TEU parcel carried by the conventional ship has been: $\lambda_{i j} P L_{i j} 0.73 \cdot 4000=2920 \mathrm{TEU}$, and that carried out by mega ship: $\lambda_{i j} \cdot P L_{i j}=0.65 \cdot 18,000=11,700 \mathrm{TEU}$.

All transport services have been carried out as planned independently of their load factor. This has implied performing the transport services along the trunk line/route regularly every: $h_{i j}=0.875$ and 3.5 days, respectively.

The intensity of collection and distribution of TEU parcels have been approximated respecting the schedules of various inland transport modes serving the chain's ports (i.e., their container terminals). The time between docking and starting unloading the ship(s) at the arriving port, and between staring loading the ship(s) again at the departing port has been chosen as an illustration (although the chosen duration could be reasonable regarding the required administrative procedures to be carried out). The ships have assumed to operate along the line/route at the constant (slow or super slow steaming) speed(s) without any substantial variations. This implies that all transport services have assumed to be perfectly punctual and reliable, i.e. carried out as the delay free along the line/route and consequently around both seaports. The inventory costs of container(s) during collection and loading at the hub supplier port (Hong Kong) and unloading and distribution at the customer port (Rotterdam) have been estimated based on the average retail value of goods in containers and typical share of the inventory costs $(25 \%)$ in that values. The costs of container time during transportation have been considered as an average for the shipments carried out by sea (EC 2009; Rodrigue 2013; VTI 2013). The handling costs of containers at the terminals of both port have been based on the empirical evidence. The costs of container ships operating on high seas have been estimated including three main components:

- The fixed costs of building and possessing the ship(s) as follows:

$\mathrm{C}_{\mathrm{F}}=-3 E-07 \cdot P L^{2}+0.0149 \cdot P L+3.358 ; R^{2}=0.999$ (The depreciation rate has assumed to be: $r=5 \%$, and the residual value at the end of age: $0.1 C_{F}$ )

- The fuel costs after quantifying the fuel consumption as follows:

Ship 4000 TEU: $F C(v)=0.0101 \cdot v^{2.9773} ; R^{2}=0.994$ (tons $/$ day); 
Table 1 Inputs for application of the models of indicators of performances of the given trunk line/route ${ }^{1)}$

\begin{tabular}{|c|c|c|}
\hline Input variable & Notation/Unit & Value \\
\hline - Period of time & $\underline{I}$ (years) & 1 \\
\hline - The TEU flows during given period of time ${ }^{2)}$ & $\underline{Q_{i j}(\tau)+Q_{j i}(\tau)}(T E U / y e a r)$ & $2,433,543$ \\
\hline \multirow{2}{*}{$\begin{array}{l}\text { - Container ship payload capacity, length, beam } \\
\text { (width) }^{3)}\end{array}$} & \multirow[t]{2}{*}{$\underline{P L_{i j} /} \underline{L_{i j} /} \underline{W_{i j}}($ TEU/ship) } & $4000 / 294 / 32$ \\
\hline & & $18,000 / 399 / 59$ \\
\hline $\begin{array}{l}\text { - Collection and distribution rate and their use for the } \\
\text { parcel of TEUs - the supplier (Hong Kong) and the } \\
\text { consumer seaport (Rotterdam) }\end{array}$ & $\frac{\theta_{j} / r_{i}}{(\operatorname{TEU} / \text { day }) /(-)}$ & 1100/1.0-1100/1.0 \\
\hline $\begin{array}{l}\text { - Loading/unloading rate per crane, the number of } \\
\text { cranes used, TEU-factor, the rate of crane use at } \\
\left.\text { the supplier seaport (Hong Kong) }{ }^{4}\right)\end{array}$ & $\frac{m_{i 1 / 2} / n_{c i} / k_{c i} / \rho_{c i l} / P L_{i j}(\text { moves } / h) /(-)}{(\text { TEU/move) } /(-) /(\text { TEU/ship) }}$ & $\begin{array}{l}36 / 3 / 1.5 / 0.75 / 4000 \\
36 / 6 / 1.5 / 0.75 / 18000\end{array}$ \\
\hline \multirow{2}{*}{$\begin{array}{l}\text { - Loading/unloading rate per crane, the number of } \\
\text { cranes used, TEU- factor, the rate of crane use - the } \\
\text { customer seaport (Rotterdam) }{ }^{4)}\end{array}$} & \multirow{2}{*}{$\frac{m_{j 1 / 2} / n_{c j} / k_{c j} / \rho_{c j i} / P L_{i j}(\text { moves } / h) /(-)}{(T E U / m o v e) /(-) /(T E U / s h i p)}$} & $42 / 3 / 1.5 / 0.75 / 4000$ \\
\hline & & $42 / 6 / 1.5 / 0.75 / 18000$ \\
\hline $\begin{array}{l}\text { - Time between collecting and loading at the supplier } \\
\text { seaport (Hong Kong), and between unloading and } \\
\text { distributing at the customer port (Rotterdam) - a TEU } \\
\text { parcel }\end{array}$ & $\underline{\Delta_{i i}} \underline{\Delta_{i j}}(\operatorname{day}(\mathrm{s}))-(\operatorname{day}(\mathrm{s}))$ & $1.0-1.0$ \\
\hline $\begin{array}{l}\text { - Operating distance between the supplier and the } \\
\text { customer seaport }{ }^{5} \text { ) }\end{array}$ & $\underline{d_{i j} / d_{i j}}(\mathrm{~nm}) /(\mathrm{nm})$ & $9748 / 9748$ \\
\hline /erage operating speed of container ships ${ }^{6}$ ) & & 20 (Slow steam \\
\hline
\end{tabular}

- Average operating speed of container ships ${ }^{6)} \quad \underline{v}_{i i}$ (kts)

20 (Slow steaming)

15 (Super slow steaming)

- Portion of the maintained average ship's operating speed

$\underline{s_{i j} / s_{i j}}(-) /(-)$

$1.0 / 1.0$

- Proportion of realized transport services

$\underline{\beta_{i j} / \beta_{i i}}(-) /(-)$

$1.0 / 1.0$

- Average delay per realized transport service

$D_{i j} / D_{i i}-D_{d i} / D_{a i}$

$0.0 / 0.0-0.0 / 0.0$ (days) $/(\mathrm{h}) /(\mathrm{h})$

$0.0 / 0.0$

- Container inventory costs - the supplier and the customer seaport $^{\text {7) }}$

$\underline{a_{i}, a_{i}}$ (\$US/TEU-day)

159; 159

- Container costs of time in transportation ${ }^{8)}$

$\underline{a_{i j}}$ (\$US/TEU-day)

13.6

- Container handling costs at the supplier seaport (Hong Kong) and the customer seaport (Rotterdam) ${ }^{9)}$

- Container ship sea/operating costs ${ }^{10)}$

$\underline{c_{i}} \underline{c_{i}}(\$ \mathrm{US} / \mathrm{TEU})-(\$ \mathrm{US} / \mathrm{TEU})$

234-200

$\frac{c_{i j} / V_{i j} / P L_{i j}}{(\$ U S / T E U-d a y) /(k t s) /}$

$14.5 / 20 ; 10.9 /$

(TEU/ship)

$15 ; 4000$

$12.1 / 20 ; 7.0 /$

$15 ; 18,000$

- Average fuel consumption of container ship at sea ${ }^{11}$

$\frac{f_{c / i i} / V_{i j} / P L_{i j}}{(\text { ton } / \text { day }) /(k t s) /}$

(TEU/ship)

$75.5 / 20 ; 32.1 /$

$15 ; 4000$

$240.2 / 20 ; 106.5$

$15 ; 18,000$

- Average emissions of GHG (Green House Gases) by container ship ${ }^{12)}$

$\frac{e_{i j} / V_{i j} / P L_{i j}(\text { tonCO }}{2 \mathrm{e} / \text { day)/ } /(\mathrm{kts}) /}$

239.3/20; 101.6/

$15 ; 4000$

$761.4 / 20 ; 337.6 /$

$15 ; 18,000$

- Average price of $\mathrm{CO}_{2}$ emissions ${ }^{13)}$

$\mathrm{C}_{\mathrm{CO}_{2}}$ (\$US/ton)

32

- Average loading/unloading time of a ship-the supplier seaport (Hong Kong) ${ }^{14)}$

$\frac{T_{i 1} / \mu_{i} / P L_{i j}}{(\text { days }) /(T E U / h) / ~}$

(TEU/ship)

$0.96 / 108 / 4000$

2.06/216/18000

- Average loading/unloading time of a ship-the customer seaport (Rotterdam) ${ }^{15)}$

$\tau_{j i} / \mu_{i} / P L_{i j}($ days $) /(T E U / h) /$

$0.82 / 126 / 4000$

(TEU/ship)

$1.71 / 252 / 18000$

- Berth's operational time and utilization ${ }^{15)}$ 
Table 1 Inputs for application of the models of indicators of performances of the given trunk line/route ${ }^{1)}$ (Continued)

\begin{tabular}{lll}
\hline Input variable & Notation/Unit & Value \\
\hline - Berth's width ${ }^{16)}$ & $\underline{S_{i / j}(\mathrm{~m})}$ & 60 \\
$\begin{array}{l}\text { Dwell time, area occupied by container, number of } \\
\text { stacks, utilization of available space, operating time } \\
\text { of container terminals }{ }^{17)}\end{array}$ & $\begin{array}{l}\bar{t}_{d / i / j} / A_{T E U / / i} / n_{c t s / i j} / \\
(\text { days }) /\left(\mathrm{m}^{2} / \mathrm{TEU}\right) /(-) /(-) /(\text { days } / \mathrm{yr})\end{array}$ & $2 / 11.5 / 3 / 365 / 0.7$ \\
- Rate of container ship losses ${ }^{18)}$ & $\underline{p}$ (Number/TEU-mile) & $4.492 \cdot 10^{-12}$
\end{tabular}

${ }^{1)}$ The liner shipping trunk line/route: Hong Kong (China) - Rotterdam (The Netherlands); ${ }^{2}$ Estimated based on Fig. 6 ( $15 \%$ of the total amount of the Far East-North Europe route/market); ${ }^{3)}$ Indicators of technical/technological performances based on design; ${ }^{4)}$ (Dynamar 2015; HKMPB 2006; Mongelluzzo 2013; SCG 2013; https:// www.portofrotterdam.com/en/news-and-press-releases/apm-terminals-rotterdam-the-most-productive-terminal-in-europe/); ${ }^{5)}$ (https://sea-distances.org/); ${ }^{6)}$ (AECOM 2012; IFT 2015); ${ }^{7)}$ (REM Associates 2014; Rodrigue 2013); ${ }^{8)}$ (VTI 2013); ${ }^{9)}$ (EC 2009); ${ }^{10)}$ Based on the load factor of: 0.73 (4000 TEU/ ship) and 0.65 (18,000 TEU/ship) (Christa et al. 2008; Drewry 2017; EC 2009; UNCTAD 2017; https://shipandbunker.com/prices/); ${ }^{11)}$ (AECOM 2012; Churchill and Johnson 2012; Notteboom and Carriou 2009); ${ }^{12)}$ Based on the emission rate of 3.17 ton $\mathrm{CO}_{2 \mathrm{e}} /$ ton of fuel (IMO 2017); ${ }^{13)}$ (Synapse 2015; WRI 2016); ${ }^{14)}$ Based on the specified load factors; ${ }^{15)}$ (Ligteringen and Velsink 2014); ${ }^{16)}$ Handling the large ship-to-shore gantry cranes (Ligteringen and Velsink 2014); ${ }^{17)}$ (Dynamar 2015; Ligteringen and Velsink 2014); ${ }^{18)}$ Period: $2007-2017$ (Allianz 2017; UNCTAD 2017)

(Note: Estimation of the monetary inputs have included the appropriate adjustments respecting inflation and exchange rates of the \$US and other currencies over time)

Ship 18,000 TEU Triple E Maersk: $F C(v)=0.0505 \cdot v^{2.8265} ; R^{2}=0.999$ (tons/day) $(v$ is the ship steaming speed (kts) assumed to be constant and fully maintained during entire trip (kts)) (Rodrigue 2013a); the price of fuel as an average at two ports has taken to be: $P_{f}=447.5 \$ \mathrm{US} /$ ton;

- The operating costs as follows:

$c_{o p}=1400.3 \cdot P L^{-0,739} ; R^{2}=0.971(P L$ is the ship's capacity (TEU)).

In addition, based on the above-mentioned estimation of the fuel consumption, the corresponding emissions of $\mathrm{CO}_{2}$ (Carbon Dioxide) as the predominant GHG in the total emissions have been calculated using the emission rate of: $e_{k}=3.17$ ton $\mathrm{CO}_{2}$ /ton of fuel (No. 6 Diesel or HFO (Heavy Fuel Oil)) (IMO 2017). The fuel consumption and related emissions of $\mathrm{CO}_{2}$ during the ships' time at berths in the ports have not been taken into account. Then the average external costs have been estimated by assuming the average social costs of $\mathrm{C}_{\mathrm{CO}_{2}}=32 \mathrm{US} / \mathrm{ton}$.

The average rate of losses of container ships during the observed period of time (number/TEU-mile) has been estimated as the world's average based on the corresponding numbers - 36 ship losses and the cumulative amount of 8.0150.10 TEU-miles carried out during the period 2007-2017 (Alianz 2017; UNCTAD 2017) (The corresponding references used for the above-mentioned estimations are given in the footnote of Table 1).

\section{Analysis of results}

The results of application of the models of indicators of performances to the line container shipping trunk line/route, based on the input data in Table 1, are shown in Figs. 8, 9, 10, and 11 . 


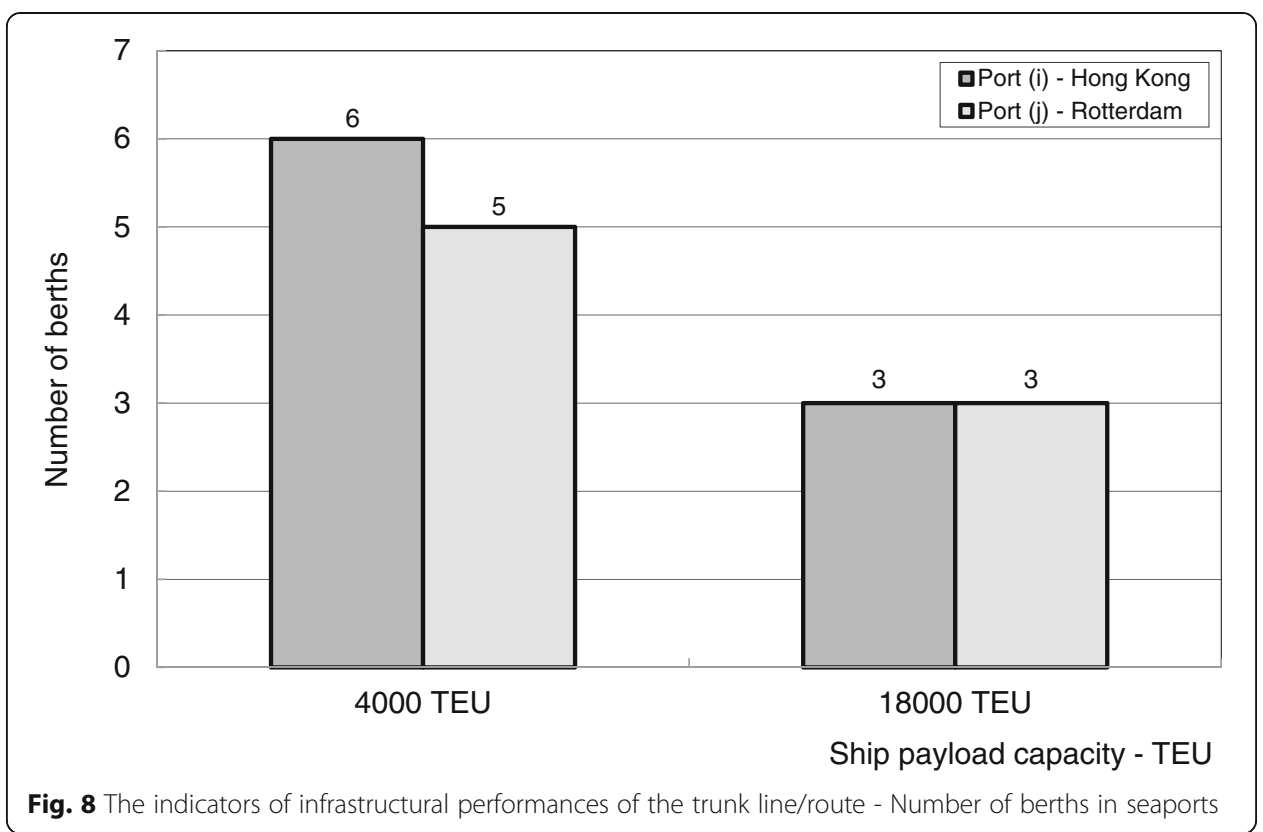

Infrastructural and technical/technological performances

The indicators of infrastructural performances of the given supply chain have been estimated and expressed in terms of the number of berths in the seaports needed to exclusively handle both categories of ships as shown on Fig. 8.

As can be seen, the number of berths in both seaports to handle the conventional ships has been for about twice higher than that for handling the mega (ULC) ships. The number of cranes deployed per berth -3 in the former and 6 in the latter case under conditions of their total equivalent capacity serving the given annual volumes of TEU flows has influenced such difference. In addition, the number of berths for handling the conventional ships at the port Hong Kong has been a bit higher, just due to the slightly lower crane capacity (36 vs 42 moves/h) (See also Table 1 ). The number of berths for handling the mega ships has been equal in both ports despite differences in the crane capacity. This has been mainly due to rounding the outcomes to the higher values. As well, all these values have been highly influenced by a rather low utilization rate of berths of about $30 \%$, aiming at preventing substantive congestion and delays of ships due to eventual irregularities in their arrival and service times. Under conditions of a relatively "perfect" regularity of the arrival and service times as practiced by many liner shipping companies transporting containers nowadays and consequent increasing of the utilization of berths, let's say, to $75 \%$, the required number of berths in both ports would be 2 for the conventional and 1 for the mega ships, respectively.

The indicators of technical/technological performances for both ship categories and two ports have been already given as inputs in Table 1 .

\section{Operational performances}

The indicators of operational performances of the trunk line/route expressed by the transport service frequency, ship fleet size, transport work, and technical productivity are shown on Fig. 9 (a, b, c, d). 

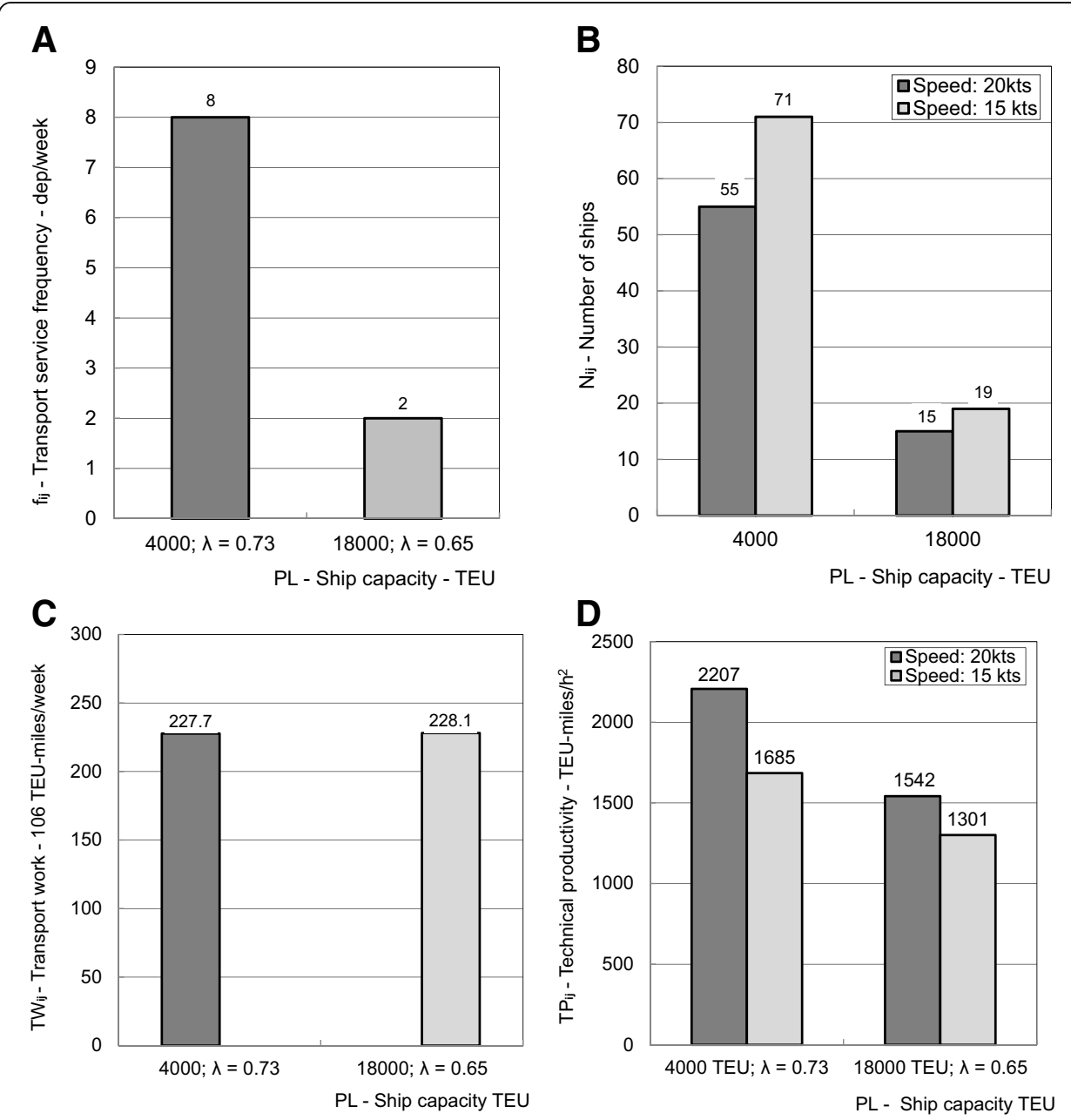

Fig. 9 The indicators of operational performances of the given trunk line/route. a Transport service frequency b Ship fleet size c Transport work d Technical productivity

Figure 9a shows that the transport service frequency by the conventional ships has needed to be for about four times higher than that by the mega (ULC) ships in order to transport the given volumes of TEU flows under given conditions. Figure $9 \mathrm{~b}$ shows that in order to perform such higher transport service frequency, the larger (for more than three times and half) fleet of the conventional ships would need to be deployed. In addition, the size of ship fleet would increase if operating at the super slow (15 kts) instead of the slow (20 kts) steaming speed - for about 30\% at the conventional and $25 \%$ at the mega ships. Figures $9 \mathrm{c}$ shows that thanks to the balanced transport service frequencies, the transport work carried out has appeared almost equal at both categories of ships. Figure 9d shows that the technical productivity of the trunk line/route has decreased with decreasing of the steaming speed of either category of ships. The decrease has been about $25 \%$ in the case of conventional and 16\% in the case of mega (ULC) ships. At the same time, this productivity would be higher if the conventional instead of the mega ships were used - for about 30\% if operating at either slow or super slow steaming speed. The main reason for such difference has been the longer inventory 


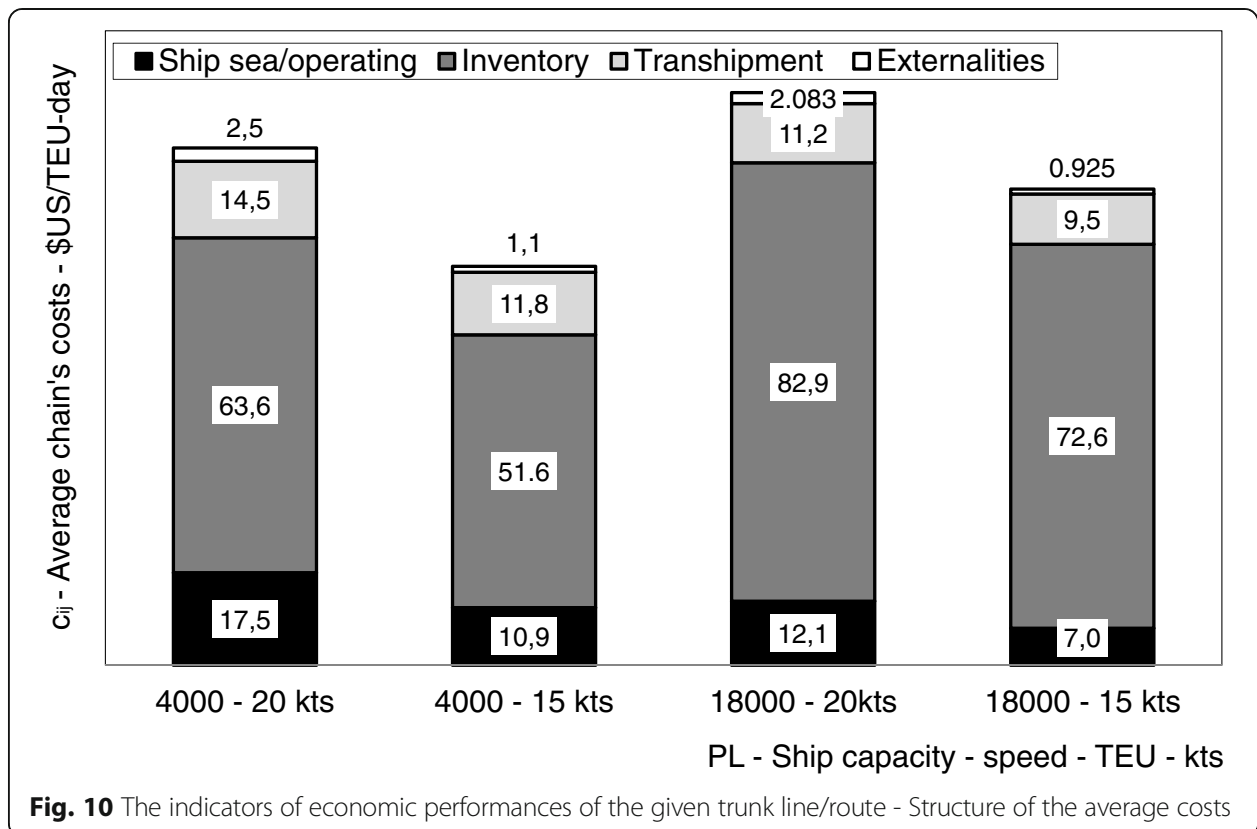

time of the TEU parcels at both ports during their collection and distribution to be transported by the mega (ULC) ships.

\section{Economic performances}

The indicators of economic performances of the given liner shipping trunk line/route have been estimated as the average costs per a TEU per unit of time as shown on Fig. 10.

As can be seen, the line's average total costs for both categories of ships and their operating speeds have included the "ship/sea operating", "inventory", "transhipment", and "externality" component. These total costs of both categories of ships have been generally lower when operating at the super slow steaming speed (15 kts), than otherwise. The difference has been about $14 \%$ at the conventional and 16\% at the mega container ship fleet. At the conventional ship fleet, the sea/operating costs has been lower for about $60 \%$ if operating at the super slow steaming speed. At the mega ship fleet, this difference has been even higher - about $73 \%$. At the same time, these costs have generally been lower at the mega ships for about $45 \%$ if operating at the slow and for about $56 \%$ if operating at the super slow steaming speed. These have confirmed the current practice of the most line shipping carriers of deploying larger ships on the one hand and operating them at the lower speeds at the other. As far as the inventory costs are concerned, they have been lower when operating at lower speed - for about $23 \%$ at the conventional and for about $14 \%$ at the mega ship fleet. The main reason has been that these total costs have spread over the longer delivery time caused by operating at the lower speed. In addition, as in case of operating at the slow and the super slow steaming speed, the inventory costs have been higher at the mega (ULC) ship fleet than at its smaller counterpart for about 30\% and 40\%, respectively. As well, the transhipment costs at both ship fleets have been lower when operating at the lower speed than otherwise, again thanks to their spreading over the longer delivery time: for about $23 \%$ at the conventional and for $18 \%$ at the mega (ULC) ship fleet. At the same time, these costs 


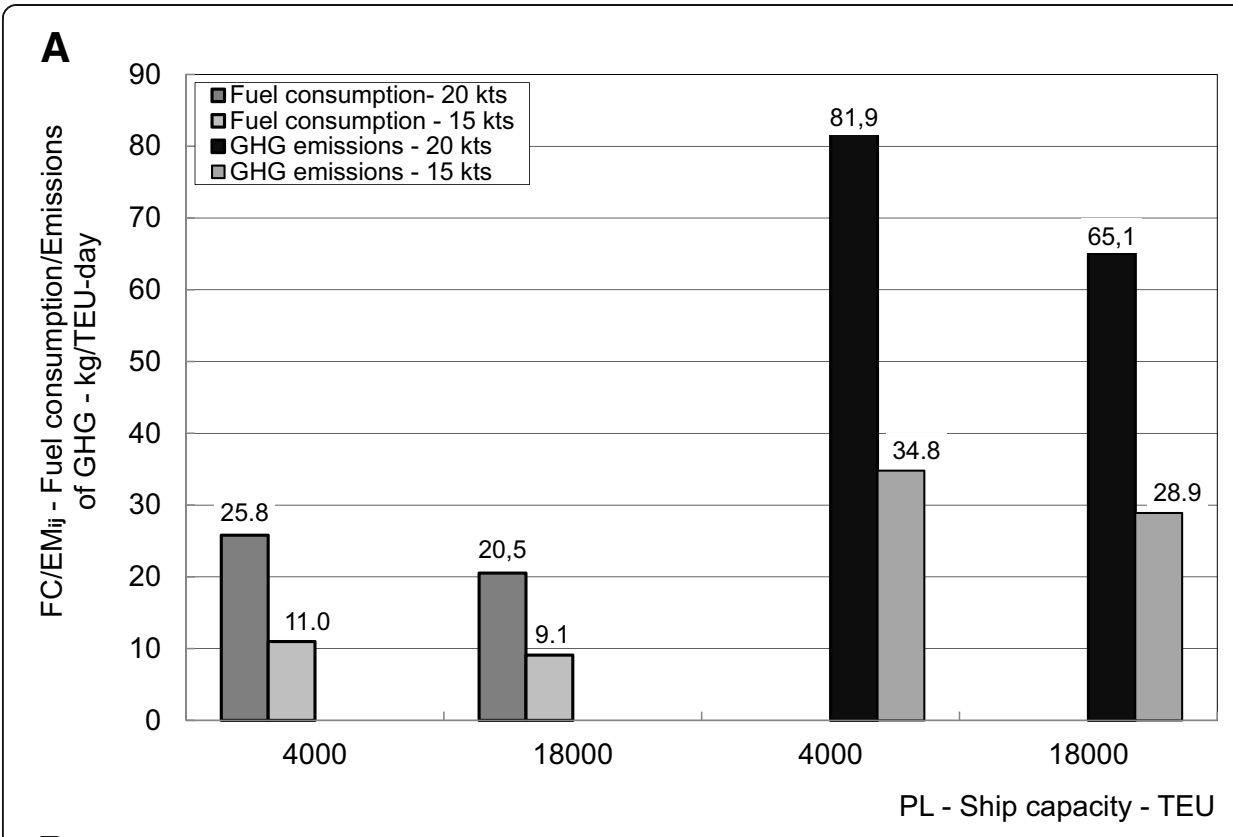

B

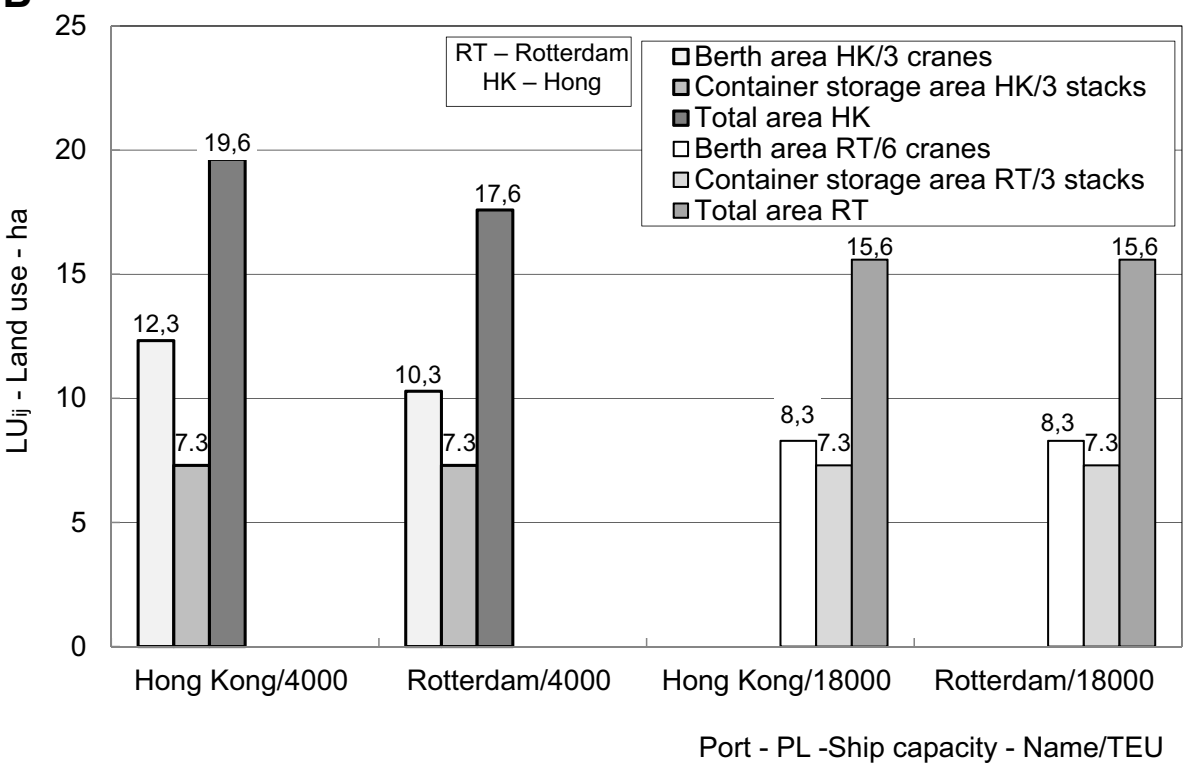

Fig. 11 The indicators of environmental performances of the trunk line/route. a Fuel consumption and emissions of GHG. b) Land use

have been higher at the conventional than at the mega (ULC) ships for about $30 \%$ when operating at the slow and $24 \%$ when operating at the super slow steaming speed. As far as the average externalities in terms of the social costs of emissions of GHG $\left(\mathrm{CO}_{2}\right)$ have been concerned, the mega (ULC) ships have also shown an advantage. However, this has not improved the corresponding total line's cost performances compared to their conventional counterparts (See sub-section 4.3.4 below for details on estimating the emissions of GHG). Consequently, the total average trunk line's costs have been higher for about $11 \%$ and $20 \%$ when being operated by the mega (ULC) ship fleet sailing at slow and super slow steaming speed, respectively. These have again confirmed some doubts and concerns on the actual cost-efficiency of deploying the mega (ULC) ships 
anyway, particularly if the costs of entire trunk line/route need to be taken into account.

\section{Environmental performances}

The indicators of environmental performances of the given trunk line/route have been estimated and expressed in terms of the ships' fuel consumption and related emissions of GHG, and land use at ports as shown on Fig. 11 (a, b).

Figure 11a shows that the average fuel consumption has generally been lower if operated at the super slow steaming speed than otherwise - for about 2.34 and 2.22 times at the conventional and the mega (ULC) ships, respectively. This confirms strategy of the line container-shipping carriers to operate their ships at as low as possible speeds but always respecting the users/market requirements. In such a way, in addition to lowering sea/operating costs, they contribute to reducing emissions of GHG and thus to "greening" container shipping by operations. In addition, the average fuel consumption and related emissions of GHG have been lower for about $26 \%$ and $20 \%$ at the mega (ULC) ship fleet than at its smaller conventional counterpart, if operated at the slow steaming and the super slow steaming speed, respectively.

Figure 11b shows the estimated land use for the berth area and the storage area of container terminals in both seaports hosting both categories of ships. As can be seen, the required berth area for hosting the conventional ship fleet has been for about $20 \%$ larger at the Hong Kong than at the Rotterdam seaport, mainly due to the lower crane capacity at the former seaport. Since the container storage area has been the same, the difference in the total area of used land has been larger in the Hong Kong seaport for about $11 \%$. In hosting the mega ship fleet, the berth, storage, and total area of land taken has been approximately the same at both seaports. There have been however differences in the land taken at the particular seaports for hosting particular categories of ship fleets. At the Hong Kong port, the berth and total area of land taken in case of hosting the conventional ships has been higher for about $48 \%$ and $27 \%$ than in case of hosting their mega counterparts. The main reasons have been the need for higher number of berths assumed to operate with the lower overall crane capacity. Similarly, in the case of hosting the conventional ships at the Rotterdam port, the berth and total area of land taken has been larger for about $24 \%$ and $13 \%$, respectively. Such lower difference has been caused by the lower number of needed berths for these ships ( 5 vs 6 in the Hong Kong port) and the higher overall crane capacity (42 vs 36 moves/h) (See Fig. 8 and Table 1).

\section{Social performances}

As mentioned above, due to the scope of consideration relating exclusively to the impacts of the given trunk line/route, the noise impact has not been considered. This is because of not including the inland collection and distribution of containers to/from the seaports from/to their ultimate suppliers and customers. In addition, the congestion and delays have not been considered after assuming that a rather low utilization of berths in both ports has neutralized any irregularity in handling the incoming and outgoing ships. As far as the safety is concerned, the estimated rate of losing container ship is given in Table 1. Applied to the given trunk line/route, it has given: $4.492 \cdot 10^{-12}$ 
Losses/TEU-mile $\cdot 9748$ mile $\cdot 2,443,543$ TEU/year $=0.1074$ Losses/year (just as an estimate). Does this imply that the safety in the given chain is satisfactory high? The answer is "yes" under given conditions.

\section{Qualitative summary and evaluation}

In summary, the exclusively used mega (ULC) ship fleet would bring advantageous (lower values) to 9, disadvantageous (higher values) to 3 , and neutral (no influence or almost equal values) to 2 indicators of performances of the given trunk line/route compared to its conventional counterparts under given conditions. The first cluster has included the number of berths in the seaports, transport service frequency, ship fleet size, sea/operating and transhipment costs, externalities, fuel consumption and related emissions of GHG, and land use. The second cluster included the total line's costs and their component - inventory costs, and technical productivity. The last cluster has included transport work and safety.

The lower sailing speed of both categories of ships has been advantageous for 6 trunk line's indicators of performances by contributing to their decreasing. These have been the total line's costs and their components (sea/operating and transhipment costs, and externalities), fuel consumption and related emissions of GHG. At the same time, it has been disadvantageous for 3 indicators of performances - by contributing to increasing of the ship fleet size and inventory costs, and decreasing of the technical productivity. Finally, it has been neutral or without any influence on 5 indicators of the line's performances such as the number of berths in ports, transport service frequency, transport work, land use, and safety (this latest only ultimately).

\section{Conclusions and discussion}

This paper has dealt with the multidimensional examination of performances of a given trunk line/route of a liner container-shipping network serving an intercontinental supply chain by the conventional (Panamax Max) and the mega (ULC - Ultra Large Container) ships. For such a purpose, the indicators of the trunk line's infrastructural, technical/technological, operational, economic, environmental, and social performances have been defined and their analytical models developed. The models of indicators of performances have been applied by using the data from the line container-shipping network spreading between Far East Asia and North Europe, and specifically from the trunk line/route connecting the seaports of Hong Kong (China) and Rotterdam (The Netherlands) operating according to "what-if" scenario approach.

The results have shown the following:

The number of berths in the seaports at both ends of the given line/route needed to handle ships carrying a given volumes of TEU flows during the given time (one year) has been crucially dependent on the capacity (number, handling rate, operating time) of cranes deployed per berth. Consequently, the higher deployed carne capacity has implied the lower number of needed berths, in this case intended to the mega ships.

The transport service frequencies by the conventional have been much higher than that by the (ULC) mega ships. Consequently, the ship fleet of the former category has been substantively larger. However, the fleet of both ship categories have increased in the cases of applying the super slow instead of the slow steaming speed. Thanks to 
balancing the transport service frequencies the transport work carried out along the line/ route by both categories of ships have been almost equal. However, the technical productivity has been lower at the mega (ULC) ship fleet. This has been due to decreasing the average speed of TEU flows along the line/route caused by their longer inventory time during collection and distribution at both seaports. The lower steaming speed has also affected the technical productivity of both ship fleets operating under given conditions.

The average trunk line's total costs and their structure have been highly sensitive to the ships' payload capacity, its utilization, and the operating speed. In general, these costs have been dominated by the substantive inventory costs. Consequently, despite the lower sea/operating, transhipment, and the external costs, the line's total costs of mega (ULC) ships have been higher than that of their conventional counterparts.

The average fuel consumption and related emissions of GHG have been again lower at both categories of ships when operating at the lower steaming speed. However, they have been lower at the mega (ULC) ships just due to spreading over the larger number of TEUs, all other conditions being constant.

In addition, the land used at both line's seaports handling the conventional ships has been different, influenced by the required number of port berths, and their crane capacity. It has been almost equal in both seaports if handling the mega (ULC) ships. In addition, the land used has been generally greater when handling the conventional ships compared to that when handling their mega (ULC) counterparts.

The actually rough estimate has indicated that the given trunk line/route would be, at least from the statistical point of view, safe.

The above-mentioned results suggest a kind of the potential advantages and disadvantages for the main actors/stakeholders dealing with the mega (ULC) ship fleets. These can be integrators/coordinators of services, ports, line shipping carriers, transport operators providing the seaport inland services, and users (shippers and receivers of containers). In particular, the integrators/coordinators of services could expect a disadvantage in terms of the higher total average operating costs mainly due to the substantively higher inventory costs. The seaports could expect an advantage in terms of less frequent calls and consequent smaller area of land used by the smaller number of required berths equipped by the adequate container handling capacity. In addition, these seaports could experience a disadvantage due to the need for providing a larger space in the container terminals for the short-term container storage. The line shipping carriers could expect the advantages in terms of deploying the smaller ship fleet(s) at the lower sea/operating costs, this latter thanks to the economies of scale enabling offering more competitive prices of transport services. A disadvantage could be in terms of deploying the larger fleet(s) caused by increasing of the ships' turnaround time along the line/route due to operating at the lower speeds and the longer seaport (inventory) time during collecting and distributing the TEU flows. The transport operators providing the seaport inland services could generally have an advantage in terms of a better utilization of the existing capacities or even increasing them. Users (container shippers and consignees) could have an advantage in terms of the lower prices of transport services. However, the disadvantage could be in terms of the longer total delivery time of shipments due to the longer inventory and transport time - the former caused by the longer collection and distribution time at the seaports and the latter by the lower transport speed. 
Further research could contribute to resolving the increasing dilemmas of the particular actors/stakeholders about the overall feasibility of using the mega (ULC) ships. First, this includes performing an additional estimation of the indicators of performances of the trunk lines/routes and the entire liner container-shipping networks serving the intercontinental supply chains based on the more realistic data for the particular above-mentioned (assumed) inputs. Second, considering and including the indicators of performances of the seaport inland transport modes and their systems in order to embrace the door-to-door delivery of TEU flows and expanding the set of indicators of the environmental and social performances can be of value. In the latter case, on the one hand, this could be inclusion of the indicators on the impacts of the seaport inland transport modes and their systems on the local population. On the other, these could be also indicators relating to the local and global social effects (benefits) of the entire liner container-shipping networks and the supply chains they serve under given conditions. Fourth, the proposed and updated models of indicators of performances could be applied to the other cases of the liner container-shipping networks serving the intercontinental supply chains according to the same and/or different scenarios. Last but not least, synthesising the findings from the elaborated cases and drafting some suggestions/recommendations for the particular abovementioned actors/stakeholders involved could be of both scientific but also practical value.

\section{Endnotes}

${ }^{1}$ The Panamax Max ship has the payload capacity of 3001-5100 TEU. The mega (ULC) ship has the payload capacity greater than 10,000 TEU (MAN 2009)

${ }^{2}$ The liner container shipping is transporting containers by the high-capacity container ships along the regular routes and according to the fixed schedule (Drewry 2015).

${ }^{3}$ The TEU-factor converts the number of both 20 - and $40-\mathrm{ft}$ containers into $20-\mathrm{ft}$ equivalent (TEU) (Ligteringen and Velsink 2014).

${ }^{4}$ Fixed ship costs: Based on the depreciation equivalent-annual-cost method, these are estimated as follows: $c_{F}(P L)=\left[D(P L) \cdot C_{F}(P L) \cdot\left\{[r(1+r)]^{N} /\left[(1+r)^{N}-1\right]\right\}\right] /(P L \cdot 360)$ (\$US/TEU-TU) $\left(C_{F}(P L)=a \cdot P L^{2}+b \cdot P L+c\right)$. The first term is the proportion of the ship's depreciation value $(\approx 0.9$ implying that the residual value of container ships is $10 \%$ ). The second term is the price of ship (in $10^{6} \$ \mathrm{US}$ ). The third term is the capital recovery factor ( $r$ is the annual interest rate (\%); $N$ is the ship's depreciation period (usually 20 years); $P L$ is the capacity of a ship (TEU/ship); $a, b, c$ are empirically derived coefficients). Fuel costs: $c_{f}(P L)=\left[F C(P L, v) \cdot P_{f}\right]=\left[d \cdot v(P L)^{e}\right] \cdot P_{f}(\$ \mathrm{US} / \mathrm{TU})(d, e$ are empirically derived coefficients; $F C(P L, v)$ is fuel consumption (tons/day); $P_{f}$ is the fuel price (\$US/ton)). Operating ship costs: $c_{o p}(P L)=g \cdot P L^{-h}$ (\$US/TEU-TU) $(g, h$ are empirically derived coefficients) (TU $\equiv$ day) (Christa et al. 2008; Drewry 2017; Sys et al. 2008; UNCTAD 2017).

${ }^{5}$ In the year 2017, this chain (sea shipping route/trading market) included in the WCI (World Container Index) shared about 40\% of the total TEU volumes transported along 3 world's East-West most voluminous global container chains (sea trading routes/markets) (UNCTAD 2017; http://www.worldcontainerindex.com/).

\section{Abbreviations}

$\mathrm{CO}_{2}$ : Carbon Dioxide; DWT: Dead Weight Tonnage; EC: European Commission; ETE: End-to-end; GDP: Gross Domestic Product; GHG: Green House Gases; GSF: Global Shipper Forum; h: Hour; H\&S: Hub-and-Spoke; HKMP: Hong Kong Maritime and Port Board; IMO: International Maritime Organization; km: Kilometre; kt: Knot; MPC: Multi-Port-Calling; nm: Nautical mile; O-D: Origin-Destination; PMS: Performance Measurement System; RTW: Round-the-world; SCM: Supply 
Chain Management; SCP: Supply Chain Performances; TEU: Twenty Foot Equivalent Unit; ULC: Ultra Large Container (ship); UNCTAD: United Nations Conference on Trade and Development; WCI: World Container Index; WEF: World Economic Forum

\section{Availability of data and materials}

All data generated or analyzed during this study are included in this published article.

\section{Authors' contributions}

Not Applicable (I am the sole author of this article). The author read and approved the final manuscript.

\section{Authors' information}

Dr. Milan Janić is a transport and traffic engineer and planner. At present, he is a Senior Researcher at the Delft University of Technology (The Netherlands) and Research Professor at the University of Belgrade (Serbia). Previously, he used to be a Leader of Research Program and Senior Researcher at the Manchester Metropolitan University, Loughborough University, and Institute of Transport of the Slovenian Railways. Dr. Janić has been involved in many research and planning projects at both national and international scale for almost forty years. He has also published numerous papers in peer-reviewed journals. In addition to contributing to many edited books, he has been the author of the books such as: "Transport Systems: Modelling, Planning and Evaluation", "Transportation Engineering: Theory, Practice and Modelling" (co-author), "Advanced Transport Systems: Analysis, Modelling, and Evaluation of Performances", "Greening Airports: Advanced Technology and Operations", "Airport Analysis, Planning and Design: Demand, Capacity and Congestion", "The Sustainability of Air Transportation: A Quantitative Analysis and Assessment", and "Air Transport System Analysis and Modelling: Capacity, Quality of Services and Economics".

\section{Competing interests}

The author declares that he has no competing interests.

\section{Publisher's Note}

Springer Nature remains neutral with regard to jurisdictional claims in published maps and institutional affiliations.

Received: 17 January 2018 Accepted: 4 December 2018

Published online: 19 December 2018

\section{References}

AECOM (2012) NC maritime strategy: vessel size vs. cost. Prepared for North Carolina Department of Transportation, AECOM Technology Corporation/URS Corporation, Los Angeles

Agarwal R, Ergun Ö (2008) Ship scheduling and network design for cargo routing in liner shipping. Transp Sci 42:175-196

Agarwal R, Ergun Ö (2010) Network design and allocation mechanisms for carrier alliances in liner shipping. Oper Res 58: $1726-1742$

Alianz (2017) Safety and shipping review 2017: an annual review of trends and developments in shipping losses and safety. Allianz Global Corporate \& Specialty, London, UK

Alvarez JF (2009) Joint routing and deployment of a fleet of container vessels. Maritime Economics \& Logistics 11:186-208

Associates REM (2014) Methodology of calculating inventory carrying costs. In: REM Associates management consultants. Princeton, New Jersey

Bassan S (2007) Evaluating seaport operation and capacity analysis-preliminary methodology. Marit Policy Manag 34:3-19. https://doi.org/10.1080/03088830601102725

Brouer BD, Alvarez JF, Plum CEM, Pisinger D, Sigurd MM (2014) A base integer programming model and benchmark suite for liner-shipping network design. Transp Sci 48:281-312

Christa Sys C, Blauwens G, Omey E, Van De Voorde E, Witlox F (2008) In search of the link between ship size and operations. Transp Plan Technol 31:435-463. https://doi.org/10.1080/03081060802335109.

Christiansen M, Fagerholt K, Nygreen B, Ronen D (2013) Ship routing and scheduling in the new millennium. Eur J Oper Res 228:467-483

Churchill J, Johnson B (2012) Saving billions on bunkers. Maersk Post (May), pp 9-12

Cullinane K, Khanna M (2000) Economies of scale in large container ships. JTEP 33:185-208

Daganzo C (2005) Logistics systems analysis, 4th edn. Springer Berlin Heilderberg, New York

Davidson N (2014) Global impacts of ship size development and liner alliances on port planning and productivity. IPAH midterm conference for planning and investment. Sydney, April 2014

Drewry (2015) Key trends in the container shipping industry. Presentation for Clecat's FFF 2015 in Antwerp. Maritime Research, London www.drewry.co.uk

Drewry (2017) Ship operating costs annual review and forecast 2017/18. Maritime Research, London

Du Y, Meng Q, Wang S (2017) Mathematically calculating the transit time of cargo trough a liner shipping network with various trans-shipment policies. Maritime Policy \& Management44:248-270. https://doi.org/10.1080/03088839. 2016.1274831

Ducruet C (ed) (2018) Maritime networks: spatial structures and time dynamics. Routledge Studies in Transport Analysis. Routledge, Abington, Oxon

Ducruet C, Notteboom T (2012) Developing Liner Service Networks in Container Shipping Chapter 6. In: Song DW, Panayides P (eds) Maritime Logistics: A complete guide to effective shipping and port management. Kogan Page, London ISBN 978 074946369 4: 77-100

Dynamar (2015) Container throughput \& terminal capacity in North Europe II. Dynamar B. V, Alkmaar www.dynamar.com 
EC (2009) Terminal handling charges during and after the liner conference era. European Commission. Publication Office of the European Union, Luxembourg

Ferrari C, Parola F, Tei A (2015) Determinants of slow steaming and implications on service patterns. Marit Policy Manag 42: 636-652. https://doi.org/10.1080/03088839.2015.1078011

Furuichi M, Otsuka N (2018) Examining quick delivery at an affordable cost by the nsr/scr-combined shipping in the age of mega-ships. Marit Policy Manag. https://doi.org/10.1080/03088839.2018.1473656

Gelareh S, Nickel S, Pisinger D (2010) Liner shipping hub network design in a competitive environment. Transp. Res. E 46:991-1004

Gelareh S, Pisinger D (2011) Fleet deployment, network design and hub location of liner shipping companies. Transp. Res. E 47:947-964

Gharehgozli AH, Amir Mileski PJ, Duru O (2017) Heuristic estimation of container stacking and reshuffling operations under the containership delay factor and mega-ship challenge. Marit Policy Manag 44:373-391. https://doi.org/10.1080/ 03088839.2017.1295328

Gharehgozli AH, Roy DR, de Koster R (2016) Sea container terminals: new technologies and OR models. Maritime Economics \& Logistics 18:103-140. https://doi.org/10.1057/mel.2015.3

Grida M, Lee C-Y (2018) An empirical model for estimating berth and sailing times of mega container ships. Marit Policy Manag. https://doi.org/10.1080/03088839.2018.1452304

GSF (2016) The implications of mega-ships and alliances for competition and total supply chain efficiency: an economic perspective. Global Shippers Forum, Tunbridge Wells

Hall RW (1993) Design for local area freight networks. Transp. Res. B 27:70-95

HKMPB (2006) Port benchmarking for Hong Kong's maritime services and associated costs with other major international ports. Main report. Marine Department, Port Development and Port Security Branch, Hong Kong Maritime Port Board, Hong Kong

HKMPB (2017) A world-class hub port strengths of Hong Kong port. Hong Kong Maritime and Port Board. https:/www. hkmpb.gov.hk/en/index.html

Hsu C-I, Hsieh Y-P (2007) Routing, ship size, and sailing frequency decision-making for a maritime hub-and-spoke container network. Math Comput Model 45:899-916

Imai A, Nishimura E, Papadimitriou S, Liu M (2006) The economic viability of container mega-ships. Transp. Res. E 42:21-41

IMO (2017) Reduction of GHG emissions from ships: update of maritime greenhouse gas emissions projections. International maritime organization. Marine Environment Protection Committee, London

ITF (2015) The impact of mega-ships: case-specific policy analysis. OECD /ITF 2015, Paris www.internationaltransportforum.org

Janić M (2014) Advanced transport systems: analysis, modelling, and evaluation of performances. Springer, London

Jianfeng ZJ, Meng Q, Sun Z (2015) Liner hub-and-spoke shipping network design. Transp. Res. E 75:32-48

Kapoor R (2016) Diminishing economies of scale from megaships? Marine Money Japan Ship Finance Forum 2015. Drewry, Tokyo www.drewry.co.uk

Lau Y-Y, Ducruet C, Ng KYA, Fu X (2018) Across the waves: a bibliometric analysis of container shipping research since the 1960s. Marit. Policy Manag. 44:667-684

Leggate H, McConville J, Morvillo A (eds) (2012) International Maritime Transport: Perspectives. Routledge Advances in Maritime Research. Routledge, Abington, Oxon

Ligteringen H, Velsink H (2014) Ports and terminals. Delft Academic Press, Delft Little A (1999) A European Supply Chain (SC) survey. http://www.adlittle.be/insights/studies/pdf/european_supply_chain_survey.pdf. (July 15, 2011).

MAN (2009) Propulsion of 8000-10000 of TEU container vessels. MAN Diesel \& Turbo, Copenhagen

Meng Q, Wang S (2011) Liner shipping service network design with empty container repositioning. Transp. Res. E 47:695-708

Meng Q, Wang S, Andersson H, Thun K (2014) Containership routing and scheduling in liner shipping: overview and future research directions. Transp Sci 48:265-280

Mongelluzzo B (2013) Bigger ships and tighter supply chains shine a new light on port productivity and its importance to shippers. The Journal of Commerce. www.joc.com:11-17

Notteboom ET, Vernimmen B (2009) The effects of high fuel costs on liner service configuration in container shipping. J Transp Geogr 17:325-337

Notteboom T, Carriou P (2009) Fuel surcharge practices of container shipping lines: is it about cost recovery or revenue making? Proceedings of the 2009 International Association of Maritime Economists (IAME) Conference, Copenhagen June 2009

Panayides MP, Wiedmer R (2011) Strategic alliances in container liner shipping. Research in Transport Economics 32:25-38

Plum CEM, Pisinger D, Sigurd MM (2014) A service flow model for the liner shipping service design problem. Eur J Oper Res 235:378-386

PoR (2015) Port Statistics: a wealth of information makes it happen. Port of Rotterdam, Rotterdam portofrotterdam.com

PR (2011) Port Vison 2030. Prepared for the City Council of Rotterdam, Rotterdam

Rodrigue J-P (2013) Container shipping costs and cargo value. The Geography of Transport Systems. https://people.hofstra. edu/geotrans/eng/ch3en/conc3en/table_containershippingcosts.html

Rodrigue J-P (2013a) Fuel consumption by containership size and speed. The Geography of Transport Systems. https://www. google.com/?gws_rd=ssl\#q=Fuel+burn+of+large+container+ships/.

Rodrigue J-P, Comtois C, Slack B (2017) Evolution of containerships. The geography of transport systems, 4th edn. Routledge, London

SCG (2013) Global supply chain news: Maersk triple E cost advantages are too great to ignore. Supply Chain Digest. http:// www.scdigest.com/index.php.

Shintani K, Imai A, Nishimura E, Papadimitriou S (2007) The container shipping network design problem with empty container repositioning. Transp. Res. E 43:39-59

Song DP, Dong JX (2013) Long-haul liner service route design with ship deployment and empty container repositioning. Transp. Res. B 55:188-211

Synapse (2015) 2015 Carbon dioxide price forecast. Synapse energy economics, Inc., Cambridge, Massachusetts www. synapse-energy.com 
Sys C, Blauwens G, Omei E, Van de Vooede E, Witlox F (2008) In search of the link between ship size and operations. Transp Plan Technol 31:435-463

Tavasszy L, Minderhoud M, Perrin J-F, Notteboom T (2011) A strategic network choice model for global container flows: specification, estimation and application. J Transp Geogr 19:1163-1172

Tran KN, Haasis H-D (2015) Literature survey of network optimization in container liner shipping. Flex Serv Manuf J 27:139-179

UNCTAD (2017) Review of maritime transport 2017. United Nations Conference on Trade and Development, New York

Vad Karsten C (2015) Competitive liner shipping network design. Technical University of Denmark, DTU Management Engineering Management Science, Kongens Lyngby, www.man.dtu.dk

Van Marle G (2013) Small ports feel the heat from big box ships as cascade effect begins. The Loadstar, July 12013

VTI (2013) Value of freight time variability reductions: results from a pilot study for the Swedish transport administration. VTI notat 39A-2013. The Swedish National Road and Transport Research Institute (VTI), Stockholm

Wang L, Zhu Y, Ducruet C, Bunel M, Lau Y (2018) From hierarchy to networking: the evolution of the "twenty-first-century maritime silk road" container shipping system. Transp Rev 38:416-435

WRI (2016) Putting a price on carbon: reducing emissions. World Resource Institute, Washington D.C

Zhang M, Wiegmans B, Tavasszy LA (2009) A comparative study on port hinterland intermodal container transport: Shanghai and Rotterdam. The Fifth Advanced Forum on Transportation of China (AFTC), 17 October 2009, Beijing

Submit your manuscript to a SpringerOpen ${ }^{\circ}$ journal and benefit from:

- Convenient online submission

- Rigorous peer review

- Open access: articles freely available online

- High visibility within the field

- Retaining the copyright to your article

Submit your next manuscript at $\boldsymbol{\nabla}$ springeropen.com 